\title{
Interim Report on Task 1.4: Impurity Effects Part 1 of 2 To Lawrence Livermore National Laboratory for Contract B345772
}

M. W. A. Stewart, E. R. Vance, R. A. Day

U.S. Department of Energy

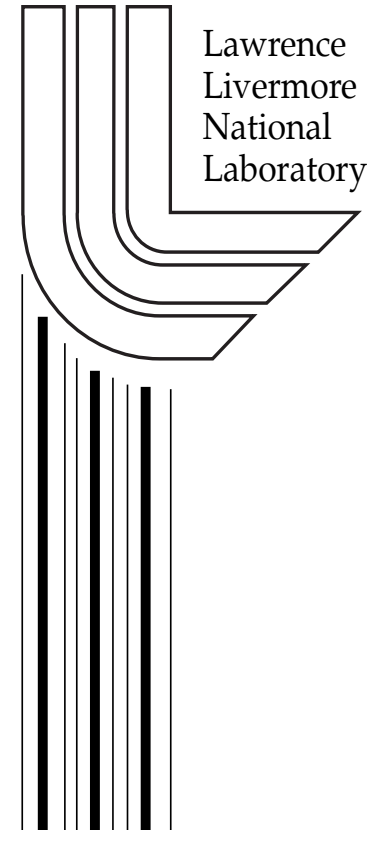

February 26, 1999 
This document was prepared as an account of work sponsored by an agency of the United States Government. Neither the United States Government nor the University of California nor any of their employees, makes any warranty, express or implied, or assumes any legal liability or responsibility for the accuracy, completeness, or usefulness of any information, apparatus, product, or process disclosed, or represents that its use would not infringe privately owned rights. Reference herein to any specific commercial product, process, or service by trade name, trademark, manufacturer, or otherwise, does not necessarily constitute or imply its endorsement, recommendation, or favoring by the United States Government or the University of California. The views and opinions of authors expressed herein do not necessarily state or reflect those of the United States Government or the University of California, and shall not be used for advertising or product endorsement purposes.

This work was performed under the auspices of the U.S. Department of Energy by University of California, Lawrence Livermore National Laboratory under Contract W-7405-Eng-48. 


\section{ansto \\ materiols division}

Interim Report on Task 1.4: Impurity Effects

Part 1 of 2

To Lawrence Livermore National Laboratory for Contract B345772

M W A Stewart, E R Vance and R A Day

26 February 1999

$\mathrm{R} 99 \mathrm{~m} 011$ 


\section{Interim Report on Task 1.4: Impurity Effects \\ To Lawrence Livermore National Laboratory for Contract B345772}

DATE ISSUED

26 February 1999

ISSUED TO

Lawrence Livermore National Laboratories

AUTHORS

Stewart, Vance and Day
APPROVED BY

E R Vance 


\section{TABLE OF CONTENTS}

1 Summary

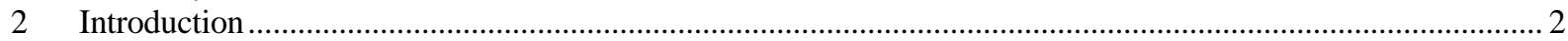

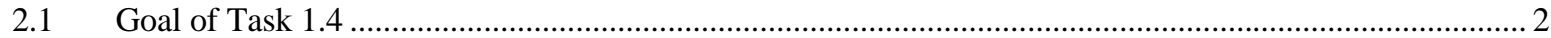

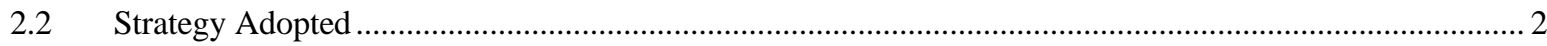

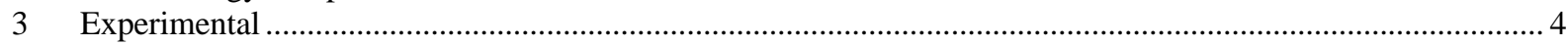

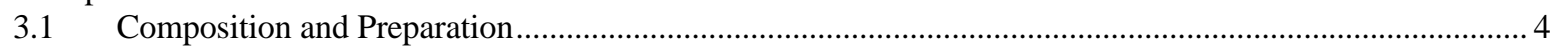

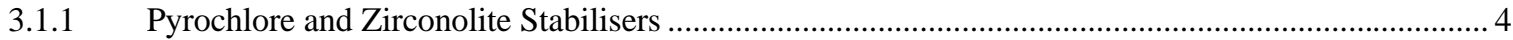

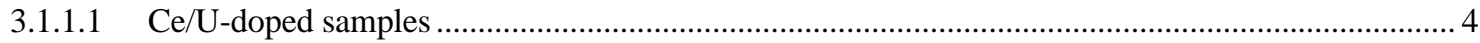

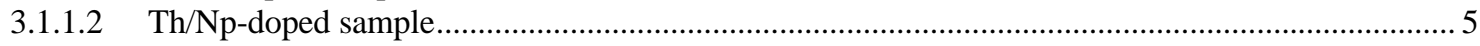

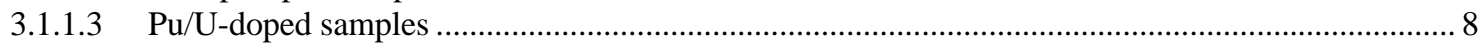

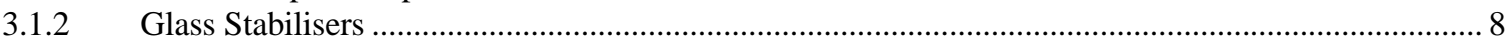

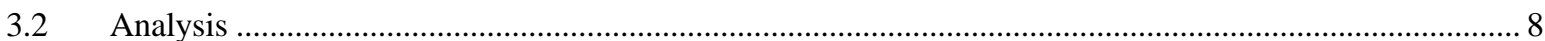

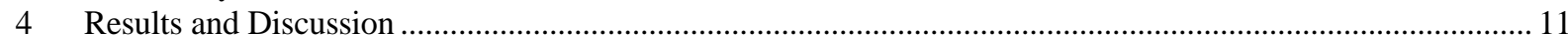

4.1 Pyrochlore and Zirconolite Stabilisers Sintered in Ar ......................................................................... 11

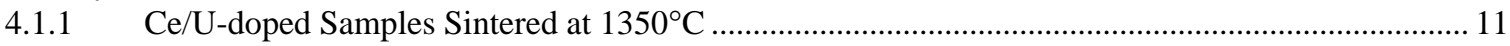

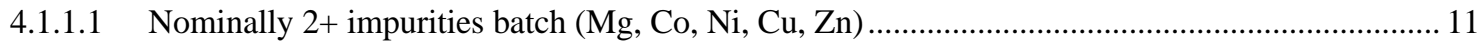

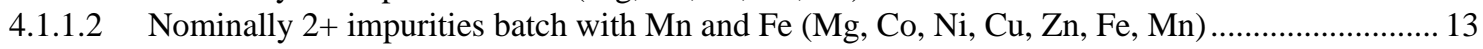

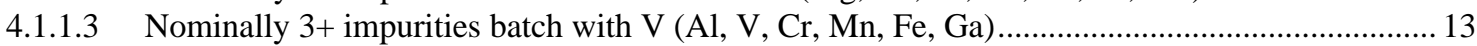

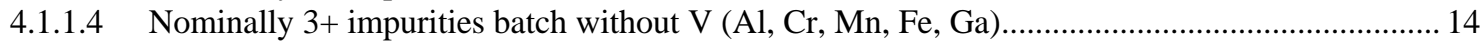

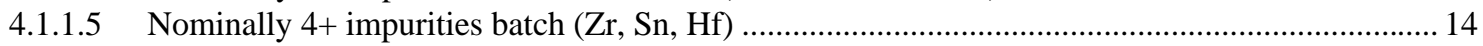

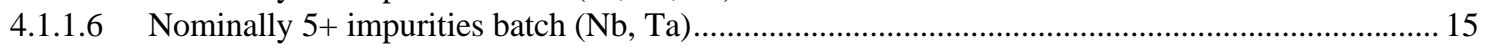

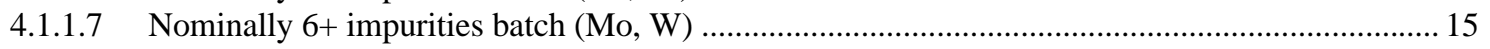

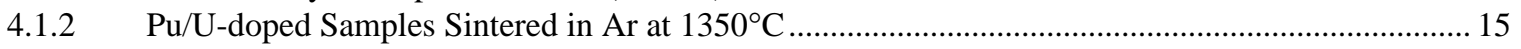

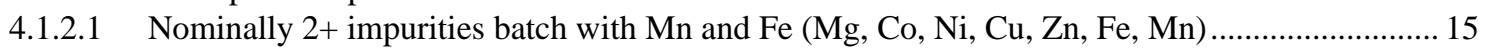

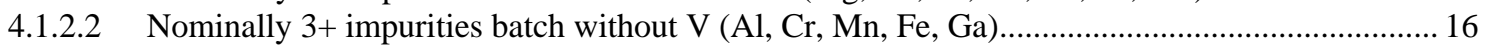

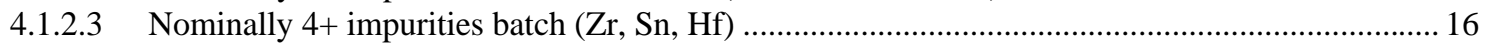

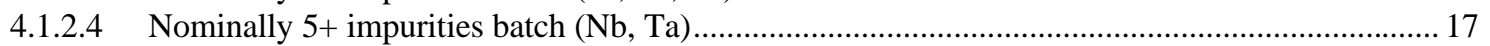

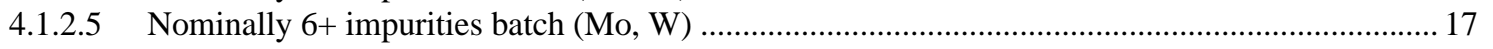

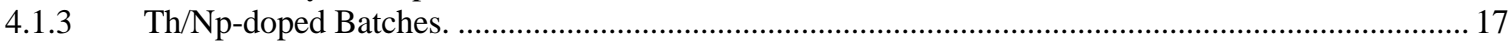

4.2 Sintering Atmosphere Effects on Pyrochlore and Zirconolite Stabilisers................................................ 18

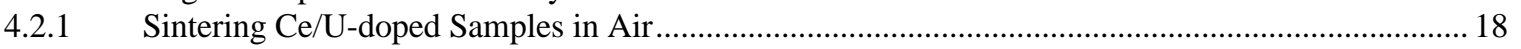

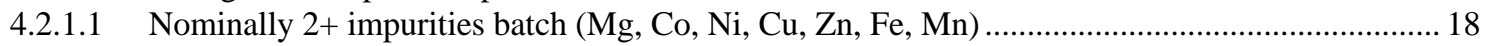

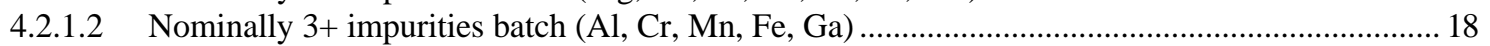

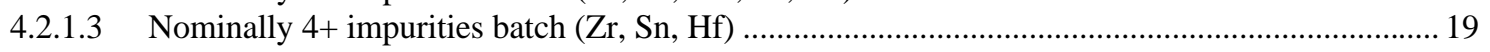

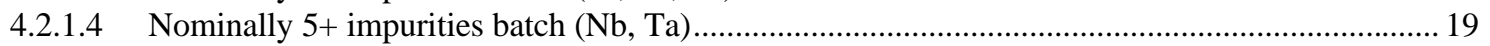

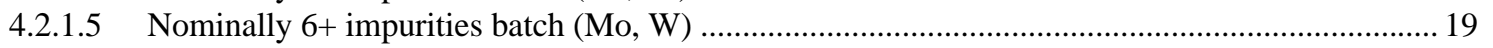

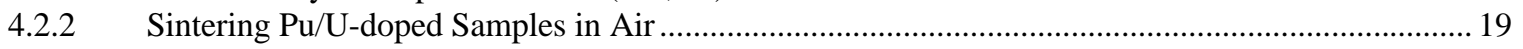

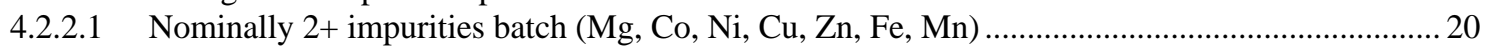

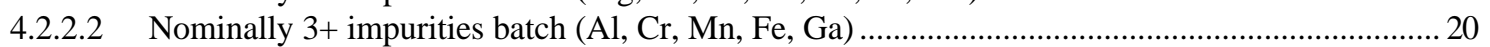

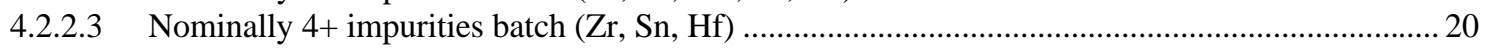

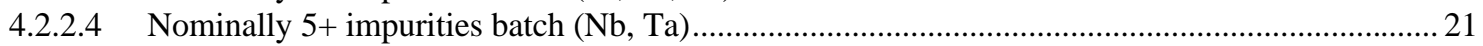

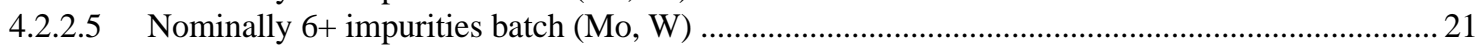

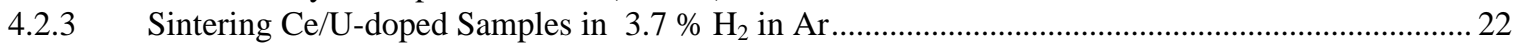

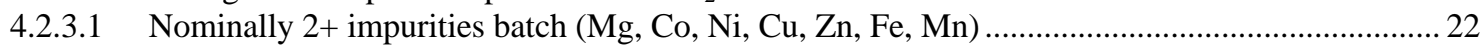

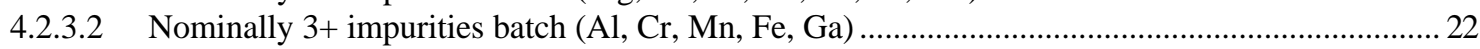

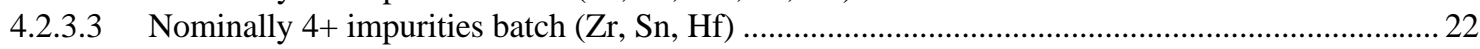

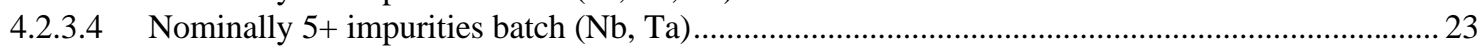

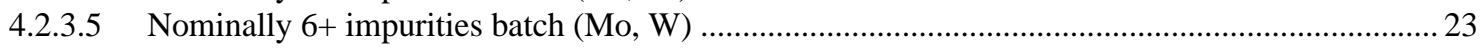

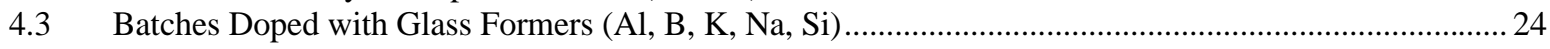

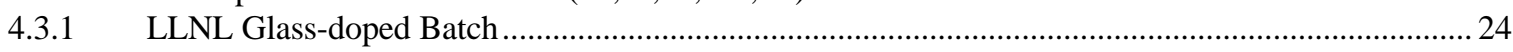

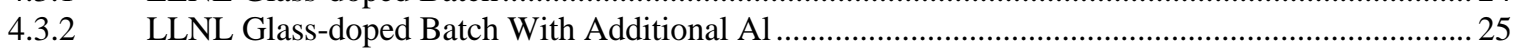

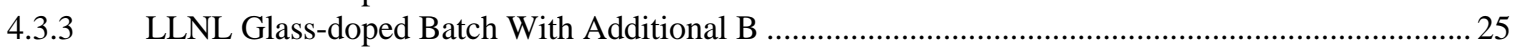

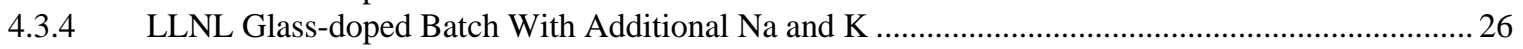

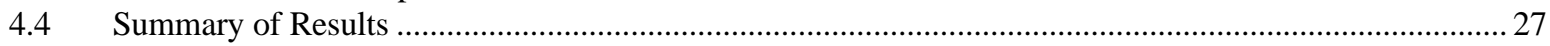

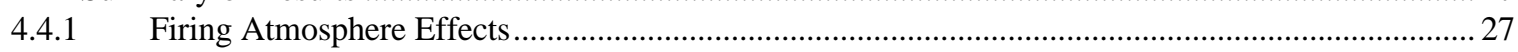

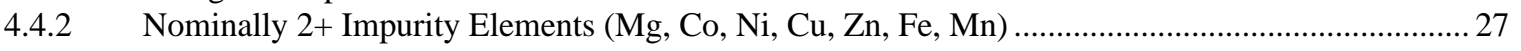

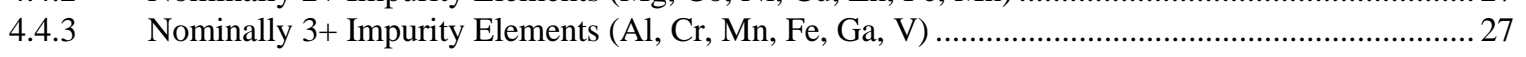




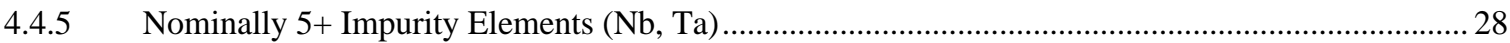

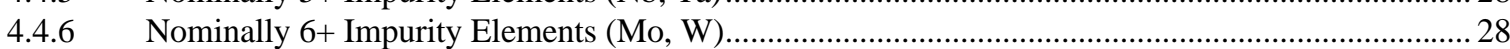

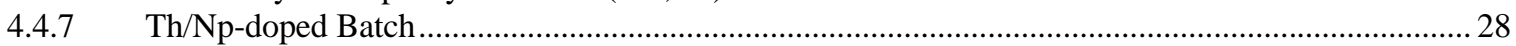

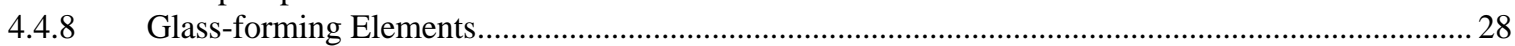

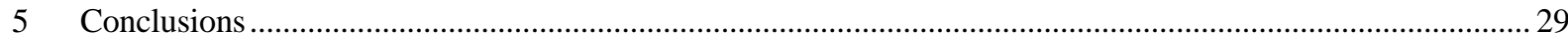




\section{SUMMARY}

From our work with baseline ceramics containing $\mathrm{Pu}$, or $\mathrm{Ce}$ substituted for $\mathrm{Pu}$, doped with sets of inactive impurity ions (with supposedly the same valency) and sintered in different atmospheres, the conclusion is that all ions of similar size and valency are indeed crystalchemically equivalent unless there are volatility problems. However, the real question appears to be what are the appropriate valency states of the multivalent impurity ions under given sintering conditions. For example, when sintered in highly reducing atmospheres (in this case $3.7 \%$ hydrogen in argon) $\mathrm{Mo}, \mathrm{W}, \mathrm{Zn}, \mathrm{Fe}, \mathrm{Cu}, \mathrm{Co}$ and $\mathrm{Ni}$ are reduced to metal.

The partitioning across the different phases present is apparently not even. The elements from the nominal $2+, 3+, 4+, 5+$ and $6+$ families will preferentially move to certain phases or result in the formation of new phases if sufficient amounts are present. If the phases of the baseline ceramic (pyrochlore-zirconolite, brannerite and rutile) are saturated with these ions, new phases will form to take up the excess impurity ions. Additional such phases detected in this work included ulvospinel, perovskite, magnetoplumbite, loveringite-like phases, metallic alloys and powellite/scheelite.

The Pu and Ce-doped samples give similar results to each other. While samples sintered in air are similar in terms of phases present (with some variations, which are discussed in the text) there are differences in the compositions of the phases.

In summary, the (probably) divalent ions $\mathrm{Mn}, \mathrm{Fe}, \mathrm{Co}, \mathrm{Ni}$, and $\mathrm{Mg}$ behave similarly, but certainly $\mathrm{Cu}$, and possibly $\mathrm{Zn}$, show some volatility losses. $\mathrm{Al}, \mathrm{Ga}, \mathrm{Cr}$, and trivalent $\mathrm{Fe}$, and $\mathrm{Mn}$, all behave similarly to each other, with some minor variations. $\mathrm{Hf}, \mathrm{Zr}$ and $\mathrm{Sn}$ also behave similarly to each other - however, the Sn is converted to the metallic state in reducing atmospheres. $\mathrm{Nb}$ and $\mathrm{Ta}$ are equivalent. Mo and $\mathrm{W}$ behaved equivalently other, but displayed significantly different partitioning ratios into the pyrochlore and scheelite/powellite phases; both reduced to metal in hydrogenous atmospheres. We contend $\mathrm{V}$ is pentavalent to at least some extent even in Ar atmospheres and acts as a flux. Of the glass formers $\mathrm{Al}$ is not equivalent to $\mathrm{B}$ as the $\mathrm{Al}$ tends to enter the crystalline phases and promotes the formation of zirconolite, whereas $\mathrm{B}$ is a much stronger glass former. $\mathrm{Na}$ is not equivalent to $\mathrm{K}$. Addition of $\mathrm{Na}$ promotes the formation of a $\mathrm{Na}-\mathrm{Ce}$ perovskite, when the ceramics are sintered in Ar, and $\mathrm{Na}$ enters the pyrochlore, zirconolite and glass. $\mathrm{K}$ was only found in the glass. Both $\mathrm{K}$ and $\mathrm{Na}$ are believed to be partially volatile under the sintering conditions tested. 


\section{INTRODUCTION}

\subsection{Goal of Task 1.4}

In the statement of work, the goal of Task 1.4 is:

"The primary goal for the impurity tests performed at ANSTO is to categorise impurities into categories of equivalence or near equivalence. For example, can $\mathrm{Al}, \mathrm{Ga}, \mathrm{Fe}, \mathrm{Cr}$ and $\mathrm{V}$ all be treated as a single impurity in the formulation where the sum of the molar quantities of the impurity determines the product properties."

The primary region of confusion with this goal is the definition of the term equivalence: clearly, no two different elements are exactly equivalent. For this work, we have assumed that ionic equivalence means equi-partitioning into the same sites in the various phases of the ceramic.

\subsection{Strategy Adopted}

The strategy adopted to determine this goal has been to initially categorise elements into families based on equivalent valency (Tables 1-5). These families of elements were then added to a baseline ceramic, nominally, $95 \mathrm{wt}$ \% pyrochlore $\left(\mathrm{Ca}_{0.89} \mathrm{Gd}_{0.22}(\mathrm{Pu}\right.$ or $\left.\mathrm{Ce})_{0.22} \mathrm{U}_{0.44} \mathrm{Hf}_{0.23} \mathrm{Ti}_{2} \mathrm{O}_{7}\right)$ and 5 wt. $\%$ rutile, $\left(\mathrm{Ti}_{0.9} \mathrm{Hf}_{0.1} \mathrm{O}_{2}\right)$. Note that the actual baseline ceramics usually consist of pyrochlore with 10-20 wt. \% brannerite and $\sim 5 \mathrm{wt}$. \% rutile and, when impurity elements are present, additional phases such as zirconolite and a glass can form. For the purposes of this work, we shall consider the primary phases to be pyrochlore-zirconolite, rutile and brannerite. The aim was to add a sufficient amount of each of these families of impurity ions ${ }^{1}$ so that the primary phases are saturated with them. Hence, secondary phases were expected to form. If the elements in the family partition approximately equally in the phase they can be considered to be equivalent.

For the glass-doped batches, initially a baseline material with $~ 13 \mathrm{wt}$. \% of LLNL glass (B3-13, see Experimental Section below) was made and sintered at 1250, 1300 and $1350^{\circ} \mathrm{C}$ for 4 hours in Ar. Additional batches were made with excess $\mathrm{B}_{2} \mathrm{O}_{3}, \mathrm{Al}_{2} \mathrm{O}_{3}, \mathrm{~K}_{2} \mathrm{O}$ or $\mathrm{Na}_{2} \mathrm{O}$. Whereas in the nominally $2+$ to $6+$ families of impurity ions equivalence is based on crystal-chemical equivalence, whereas with glasses the equivalence can be crystal chemical or physical. For example, two elements A and B may both result in the formation of a glass which contains equivalent amounts of A or B. Compared to B however, A may produce a less viscous glass, which will lower the sintering temperature required and will usually promote grain growth.

${ }^{1}$ For the $2+$ to $6+$ families, the total amount added to each batch was $\sim 13$ wt. $\%$ (with some minor 
Table 1: Families of equivalent elements tested.

\begin{tabular}{|lll|}
\hline $\begin{array}{l}\text { Nominal Ionic } \\
\text { Charge }\end{array}$ & Elements & Expected outcome \\
\hline $\begin{array}{l}2+ \\
2+\text { with } \mathrm{Mn} \text { and } \mathrm{Fe}\end{array}$ & $\mathrm{Mg}, \mathrm{Co}, \mathrm{Ni}, \mathrm{Cu}, \mathrm{Zn}, \mathrm{Ni}, \mathrm{Cu}, \mathrm{Zn}, \mathrm{Mn}, \mathrm{Fe}$ & $\begin{array}{l}\text { Zirconolite stabiliser* } \\
\text { Zirconolite stabiliser }\end{array}$ \\
$\begin{array}{l}3+ \\
3+\text { no V }\end{array}$ & $\mathrm{Al}, \mathrm{V}, \mathrm{Cr}, \mathrm{Mn}, \mathrm{Fe}, \mathrm{Ga}$ & Zirconolite stabiliser* $^{*}$ \\
$4+$ & $\mathrm{Al}, \mathrm{Cr}, \mathrm{Mn}, \mathrm{Fe}, \mathrm{Ga}$ & Zirconolite stabiliser $^{*}$ \\
$5+$ & $\mathrm{Sn}, \mathrm{Zr}, \mathrm{Hf}$ & Zirconolite stabiliser $^{\#}$ \\
$6+$ & $\mathrm{Nb}, \mathrm{Ta}$ & Pyrochlore stabiliser \\
$4+$ actinides & $\mathrm{Mo}, \mathrm{W}$ & Pyrochlore stabiliser \\
Glass formers & $\mathrm{B}, \mathrm{Si}, \mathrm{Na}, \mathrm{K}, \mathrm{Al}$ & Pyrochlore stabiliser \\
\hline
\end{tabular}

* Impurities expected to enter the Ti sites; charge compensation will take place via rare-earth and/or actinide entering the Ca sites to give $2 \mathrm{M}$ zirconolite.

\# Impurities are expected to enter the Hf-Zr site - progressive addition will drive the pyrochlore to $4 \mathrm{M}$ zirconolite and then $2 \mathrm{M}$ zirconolite. 


\section{EXPERIMENTAL}

In this work a Ce-doped (substituting for $\mathrm{Pu}$ ) precursor, of the baseline composition, was prepared (Tables 2 and 3). This is designed to give a $95 \mathrm{wt}$. \% pyrochlore, $1 \mathrm{wt} \% \mathrm{HfO}_{2}$ and 4 wt. $\% \mathrm{TiO}_{2}$ mixture. On sintering, the hafnia and titania form a solid solution $\left(\mathrm{Ti}_{0.9} \mathrm{Hf}_{0.1} \mathrm{O}_{2}\right)$.

\subsection{Composition and Preparation}

\subsubsection{Pyrochlore and Zirconolite Stabilisers}

\subsubsection{Ce/U-doped samples}

Batches of the oxide-basis compositions given in Tables 2 and 3 were prepared by the alkoxide-route using the raw materials given in Tables 4 and 5.

Two precursor batches, each of $100 \mathrm{~g}$, were made. In the first batch (mws980006), the Ca source was calcium hydroxide and the Ce source was cerium nitrate. In the second precursor (mws980069), the Ca source was calcium nitrate and the Ce source was ammonium cerium (IV) nitrate. These batches are given in Table 6.

The precursors were made as follows. The Ti and Hf alkoxides were mixed together and diluted to $50 \%$ by adding anhydrous ethanol. The non-radioactive nitrates/hydroxides $\left(\mathrm{Ca}, \mathrm{Gd}\right.$ and $\mathrm{Ce}$ ) were diluted together in deionised water and added to the alkoxides ${ }^{2}$. This batch was then shear mixed for 10 minutes. It was then taken to the uranium laboratory where uranyl nitrate was added. The sample was stirred and then dried overnight on a hot plate. The dried cake was broken up using a mortar and pestle. A loss on ignition test was performed to determine the oxide content.

Batches of $20 \mathrm{~g}$ (oxide basis) were made for each of the equivalent impurity families to be tested. The mixtures were designed to contain equimolar additions of each impurity element, with the exception of: (i) the $2+$ with $\mathrm{Mn}$ and Fe batch, which contained a lower molar level of $\mathrm{Mn}$ and $\mathrm{Fe}$; and (ii) the 4+ batch where the $\mathrm{Zr}$ was subsequently found to be deficient by $\sim 20 \%$ due to a weighing error ${ }^{3}$. The impurity raw materials (Table 5) were weighed out and mixed with water in a beaker. The required amount of precursor was added to the beaker, which was then placed in an ultrasonic bath for 30 minutes to break up the aggregates. The slurry was stirred for 10 minutes, poured into a stainless steel bowl and dried overnight on a hot plate. The dried cake was lightly ground with a mortar and pestle placed inside an alumina boat and rotary calcined in air for 1 hour at $750^{\circ} \mathrm{C}$. The calcined powder was then treated by wet ball milling (water) for 16 hours with zirconia media in a nylon jar. The milled slurry was dried at $110^{\circ} \mathrm{C}$.

$10 \mathrm{~mm}$ diameter and $\sim 0.5 \mathrm{~g}$ pellets were cold pressed at $\sim 90 \mathrm{MPa}$ and then sintered in an alumina tube furnace for 4 hours at $1350^{\circ} \mathrm{C}$. The atmospheres used were $0.25 \mathrm{l} / \mathrm{min}$. of $\mathrm{Ar}$,

\footnotetext{
${ }^{2}$ Amount of water is 4 times the weight of alkoxide.
} 
air or $3.7 \% \mathrm{H}_{2}$ in Ar. The heating and cooling rate was $5^{\circ} \mathrm{C} / \mathrm{min}$.

An additional $5 \mathrm{~g} \mathrm{2+}$ impurity batch that contained $\mathrm{Mn}$ and $\mathrm{Fe}$ in addition to the previous elements in the original $2+$ batch $(\mathrm{Mg}, \mathrm{Co}, \mathrm{Ni}, \mathrm{Cu}, \mathrm{Zn})$, was made by adding $\mathrm{Mn}$ and $\mathrm{Fe}$ nitrates to the some of original calcine (Table 2). This was mixed together as a slurry, dried, calcined and ball milled as above.

\subsubsection{Th/Np-doped sample}

This batch consisted of a mixture of (oxide-basis) $2.00 \mathrm{~g}$ of Ce/U-baseline precursor, 0.154 $\mathrm{g}$ of $\mathrm{NpO}_{2}$ and $0.149 \mathrm{~g}$ of $\mathrm{ThO}_{2}$. The composition is given in Table 7. The precursor was made by the alkoxide-route (Table 6). The $\mathrm{Np}$ and Th were added as nitrate solutions. The components were mixed in a $25 \mathrm{ml}$ glass jar, then placed in an ultrasonic bath for $30 \mathrm{~min}$. to break up the agglomerates. Drying was done in a glass beaker on a hot-plate. The dried powder was calcined at $750^{\circ} \mathrm{C}$ in air for 1 hour in a $\mathrm{Pt}$ lined, alumina boat in an alumina tube furnace. The calcined powder was dry-milled for 20 minutes using a MM 2 mixer mill ${ }^{4}$ with a zirconia grinding jar and two zirconia balls. Pellets (10 $\mathrm{mm}$ dia.) were cold pressed at $\sim 90 \mathrm{MPa}$ and sintered at $1350^{\circ} \mathrm{C}$ in Ar for 4 hours in an alumina tube furnace.

Table 2: Compositions of the Task 1.4 Ce-doped batches: precursor, and the two nominally 2+ impurity batches.

\begin{tabular}{|l|ccc|}
\hline \multirow{2}{*}{ Oxide } & \multicolumn{3}{|c|}{ Batch } \\
\cline { 2 - 4 } & $\begin{array}{c}\text { Precursor } \\
\text { (Wt. \%) }\end{array}$ & $\begin{array}{c}2+ \\
\text { (Wt. \%) }\end{array}$ & $\begin{array}{c}\text { 2+ with Mn and Fe } \\
\text { (Wt. \%) }\end{array}$ \\
\hline $\mathrm{CaO}$ & 10.43 & 9.07 & 8.84 \\
$\mathrm{CeO} 2$ & 7.91 & 6.88 & 6.71 \\
$\mathrm{CoO}$ & & 2.79 & 2.72 \\
$\mathrm{CuO}$ & & 3.00 & 2.93 \\
$\mathrm{FeO}$ & & & 1.30 \\
$\mathrm{Gd}{ }_{2} 3$ & & 7.24 & 7.06 \\
$\mathrm{HfO} 2$ & 8.33 & 9.67 & 9.43 \\
$\mathrm{MgO}$ & 11.12 & 1.49 & 1.46 \\
$\mathrm{MnO}$ & & & 1.21 \\
$\mathrm{NiO}$ & & 2.75 & 2.68 \\
$\mathrm{TiO} 2$ & 37.38 & 32.51 & 31.69 \\
$\mathrm{UO} 2$ & 24.82 & 21.58 & 21.04 \\
$\mathrm{ZnO}$ & & 3.01 & 2.93 \\
\hline Total & 100.00 & 100.00 & 100.00 \\
\hline
\end{tabular}

${ }^{4}$ Model MM 2 Mixer mill, Retsch GmbH, Rheinische Strasse 36, Haan, Germany. Grinding jar used was a $25 \mathrm{ml}$ zirconia jar with cover - Retsch code 01.462.0047. Two $12 \mathrm{~mm}$ dia. zirconia balls were used to grind 
Table 3: Compositions of the Task 1.4 Ce-doped batches: precursor, the two nominally $3+, 4+, 5+$ and $6+$ impurity batches.

\begin{tabular}{|c|c|c|c|c|c|c|}
\hline \multirow[b]{2}{*}{ Oxide } & \multicolumn{5}{|c|}{ Batch } & \multirow[b]{2}{*}{$\begin{array}{c}6+ \\
\text { (Wt. \% } \\
\end{array}$} \\
\hline & $\begin{array}{l}\text { Precursor } \\
\text { (Wt. \%) }\end{array}$ & $\begin{array}{c}3+ \\
\text { (Wt. \%) }\end{array}$ & $\begin{array}{l}3+\text { no V } \\
\text { (Wt. \%) }\end{array}$ & $\begin{array}{c}4+ \\
\text { (Wt. \%) }\end{array}$ & $\begin{array}{c}5+ \\
\text { (Wt. \%) }\end{array}$ & \\
\hline $\mathrm{Al}_{2} \mathrm{O}_{3}$ & & 1.46 & 1.51 & & & \\
\hline $\mathrm{CaO}$ & 10.43 & 9.08 & 9.27 & 9.15 & 9.07 & 9.08 \\
\hline $\mathrm{CeO}_{2}$ & 7.91 & 6.88 & 7.03 & 6.94 & 6.88 & 6.88 \\
\hline $\mathrm{Cr}_{2} \mathrm{O}_{3}$ & & 2.18 & 2.22 & & & \\
\hline $\mathrm{Fe}_{2} \mathrm{O}_{3}$ & & 2.27 & 2.34 & & & \\
\hline $\mathrm{Ga}_{2} \mathrm{O}_{3}$ & & 2.68 & 2.75 & & & \\
\hline $\mathrm{Gd}_{2} \mathrm{O}_{3}$ & 8.33 & 7.25 & 7.40 & 7.31 & 7.25 & 7.25 \\
\hline $\mathrm{HfO}_{2}$ & 11.12 & 9.68 & 9.88 & 15.50 & 9.67 & 9.68 \\
\hline $\mathrm{Mn}_{2} \mathrm{O}_{3}$ & & 2.25 & 2.35 & & & \\
\hline $\mathrm{MoO}_{3}$ & & & & & & 4.98 \\
\hline $\mathrm{Nb}_{2} \mathrm{O}_{5}$ & & & & & 4.92 & \\
\hline $\mathrm{SnO}_{2}$ & & & & 4.13 & & \\
\hline $\mathrm{Ta}_{2} \mathrm{O}_{5}$ & & & & & 8.09 & \\
\hline $\mathrm{TiO}_{2}$ & 37.38 & 32.53 & 33.21 & 32.80 & 32.52 & 32.53 \\
\hline $\mathrm{UO}_{2}$ & 24.82 & 21.60 & 22.05 & 21.78 & 21.59 & 21.60 \\
\hline $\mathrm{V}_{2} \mathrm{O}_{3}$ & & 2.15 & & & & \\
\hline $\mathrm{WO}_{3}$ & & & & & & 8.01 \\
\hline $\mathrm{ZrO}_{2}$ & & & & 2.39 & & \\
\hline Total & 100.00 & 100.00 & 100.00 & 100.00 & 100.00 & 100.00 \\
\hline
\end{tabular}

Table 4: Raw materials used for the precursor batches.

\begin{tabular}{|c|c|}
\hline Element & $\begin{array}{l}\text { Raw Materials for Alkoxide-route Batches (raw, material, source, catalogue } \\
\text { number) }\end{array}$ \\
\hline $\begin{array}{l}\mathrm{Ti} \\
\mathrm{Hf} \\
\mathrm{Gd} \\
\mathrm{Ce} \\
\mathrm{Pu} \\
\mathrm{U}\end{array}$ & $\begin{array}{l}99.995 \% \mathrm{Ca}(\mathrm{OH})_{2}, \text { Aldrich Chem. Co., } 45014-6 \text { or } \\
>99 \% \mathrm{Ca}\left(\mathrm{NO}_{3}\right)_{2} .4 \mathrm{H}_{2} \mathrm{O} \text {, Aldrich Chem. Co., 23712-4 } \\
\text { Titanium isopropoxide, HÜLS Troisdorf Gmb., } 405514 \\
99.99 \% \mathrm{Hafnium} \text { n-butoxide, Gelest Inc. } \\
99.9 \% \mathrm{Gd}\left(\mathrm{NO}_{3}\right)_{3} \cdot 6 \mathrm{H}_{2} \mathrm{O} \text {, Aldrich Chem., } 21159-1 \\
99.9 \% \mathrm{Ce}\left(\mathrm{NO}_{3}\right)_{3} \cdot 6 \mathrm{H}_{2} \mathrm{O} \text {, Aldrich Chem., } 23853-8 \text { or } \\
>98.5 \%\left(\mathrm{NH}_{4}\right)_{2} \mathrm{Ce}\left(\mathrm{NO}_{3}\right)_{2} \text {, Aldrich Chem. 43-133-8. } \\
\mathrm{Pu} \text { nitrate solution, }(\mathrm{Pu}-239) \text { made by dissolving PuO }{ }_{2} \text { in } 8 \mathrm{M} \mathrm{HNO} \mathrm{HN}_{3} . \\
\mathrm{UO}_{2}\left(\mathrm{NO}_{3}\right)_{2} .6 \mathrm{H}_{2} \mathrm{O} \text {, depleted }(\sim 0.318 \% \text { U235), BDH, Batch FF296, } 10289\end{array}$ \\
\hline
\end{tabular}


Table 5: Raw materials used for the impurity addition work in Task 1.4.

\begin{tabular}{|c|c|}
\hline Element & $\begin{array}{l}\text { Raw Materials Task } 1.4 \text { impurity elements (raw material, source, catalogue } \\
\text { number) }\end{array}$ \\
\hline $\mathrm{Mg}$ & $>99 \% \mathrm{Mg}\left(\mathrm{NO}_{3}\right)_{2} \cdot 6 \mathrm{H}_{2} \mathrm{O}$, Aldrich Chem., 23717-5 \\
\hline Co & $>99 \% \mathrm{Co}\left(\mathrm{NO}_{3}\right)_{2} \cdot 6 \mathrm{H}_{2} \mathrm{O}, \mathrm{BDH}, 100083$ \\
\hline $\mathrm{Ni}$ & $>99 \% \mathrm{Ni}\left(\mathrm{NO}_{3}\right)_{2} \cdot 6 \mathrm{H}_{2} \mathrm{O}$, Fluka, 72253 \\
\hline $\mathrm{Cu}$ & $>99 \% \mathrm{Cu}\left(\mathrm{NO}_{3}\right)_{2} .3 \mathrm{H}_{2} \mathrm{O}$, Fluka, 61194 \\
\hline $\mathrm{Zn}$ & $>99 \% \mathrm{Zn}\left(\mathrm{NO}_{3}\right)_{2} \cdot 6 \mathrm{H}_{2} \mathrm{O}$, Fluka, 96482 \\
\hline $\mathrm{Fe}$ & $+98 \% \mathrm{Fe}\left(\mathrm{NO}_{3}\right)_{3} .9 \mathrm{H}_{2} \mathrm{O}$, Ajax Chem., Univar 827 \\
\hline Mn & Mn-nitrate solution, BDH, 16658 \\
\hline $\mathrm{Al}$ & $99.6 \% \mathrm{Al}_{2} \mathrm{O}_{3}$, Degussa $\mathrm{AG}$, Aluminium Oxide $\mathrm{C}$ \\
\hline V & $>99 \% \mathrm{~V}_{2} \mathrm{O}_{3}$, Aldrich Chem., 21398-8 \\
\hline $\mathrm{Cr}$ & $>99 \% \mathrm{Cr}\left(\mathrm{NO}_{3}\right)_{3} \cdot 6 \mathrm{H}_{2} \mathrm{O}$, Fluka, 27080 \\
\hline $\mathrm{Ga}$ & $99.9 \% \mathrm{Ga}\left(\mathrm{NO}_{3}\right)_{3} .6 \mathrm{H}_{2} \mathrm{O}$, Aldrich Chem., 28989-2 \\
\hline $\mathrm{Zr}$ & Zirconium n-butoxide, HULS Troisdorf GMB., 405537 \\
\hline $\mathrm{Sn}$ & $99.9 \%, \mathrm{SnO}_{2},-325$ mesh, Aldrich Chem., 24465-1 \\
\hline Hf & $99.99 \%$ Hafnium n-butoxide, Gelest Inc. \\
\hline $\mathrm{Nb}$ & $99.95 \%, \mathrm{Nb}_{2} \mathrm{O}_{5},-325$ mesh, Cerac, N-1073 \\
\hline $\mathrm{Ta}$ & $99.9 \% \mathrm{Ta}_{2} \mathrm{O}_{5}$, A.D. MacKay Ltd. \\
\hline Mo & $\left(\mathrm{NH}_{4}\right)_{6} \mathrm{Mo}_{7} \mathrm{O}_{24} \cdot 4 \mathrm{H}_{2} \mathrm{O}$, May and Baker, L804 \\
\hline $\mathrm{W}$ & $\left(\mathrm{NH}_{4}\right)_{10} \mathrm{~W}_{12} \mathrm{O}_{41} .5 \mathrm{H}_{2} \mathrm{O}, \mathrm{BDH}, 27208$ \\
\hline $\mathrm{Si}$ & Ludox HS-40 colloidal silica, 40\% suspension in water, Aldrich Chem., 42081-6 \\
\hline $\mathrm{P}$ & $85 \% \mathrm{H}_{3} \mathrm{PO}_{4}$, Ajax Chem., \\
\hline B & $\mathrm{H}_{3} \mathrm{BO}_{3}$, Ajax Chem., Unilab 102 \\
\hline $\mathrm{K}$ & $\mathrm{KOH}$, Merck, 5033 \\
\hline $\mathrm{Na}$ & $\mathrm{NaOH}$, Merck, 6498 \\
\hline Th & $\mathrm{Th}\left(\mathrm{NO}_{3}\right)_{4} .5 \mathrm{H}_{2} \mathrm{O}$, Merck, 1.08162 \\
\hline $\mathrm{Np}$ & Np nitrate, (Np-237) AEA Tech. Harwell, 93/237/97 \\
\hline
\end{tabular}

Table 6: Precursors used for Task 1.4 batches; compositions of precursors are given in Tables 2 and 3 above.

\begin{tabular}{|l|cc|}
\hline $\begin{array}{c}\text { Nominal Impurity } \\
\text { Valency }\end{array}$ & \multicolumn{2}{|c|}{ Precursor used } \\
\cline { 2 - 3 } & Ce-doped $^{\#}$ & Pu-doped $^{\#}$ \\
\hline $2+$ & mws980069 & - \\
$2+$ with Mn and Fe & mws980069 & $5 \mathrm{~A}$ \\
$3+$ & mws980069 & - \\
$3+$ no V & mws980006 & $5 \mathrm{~A}$ \\
$4+$ & mws980069 & $5 \mathrm{~A}$ \\
$5+$ & mws980069 & $5 \mathrm{~A}$ \\
$6+$ & mws980006 & $5 \mathrm{~A}$ \\
$4+$ actinides $(\mathrm{Np} / \mathrm{Th})$ & mws980006 & - \\
Glass & mws980006 & - \\
\hline
\end{tabular}

\# see Tables 2, 3 and 8 for precursor composition. 
Table 7: Compositions of the Task 1.4 Ce-doped batch with Np and Th added.

\begin{tabular}{|l|c|}
\hline Oxide & $\begin{array}{c}\text { Composition } \\
\text { (wt. \%) }\end{array}$ \\
\hline $\mathrm{CaO}$ & 9.07 \\
$\mathrm{CeO} 2$ & 6.88 \\
$\mathrm{Gd}_{2} \mathrm{O}_{3}$ & 7.25 \\
$\mathrm{HfO}_{2}$ & 9.67 \\
$\mathrm{NpO}_{2}$ & 6.58 \\
$\mathrm{ThO}_{2}$ & 6.46 \\
$\mathrm{TiO}_{2}$ & 32.51 \\
$\mathrm{UO}_{2}$ & 21.59 \\
\hline Total & 100.00 \\
\hline
\end{tabular}

\subsubsection{Pu/U-doped samples}

Pu-doped batches (Table 8) containing the nominally 2+, 3+, 4+, 5+ and 6+ impurity families were made using an available $\mathrm{Pu}$-doped, oxide-route precursor. This precursor was chosen because it only contained small amounts of impurities and none of the glass phase formers (B, Si, Na and K). The precursor used was batch 5A (Table 8) made in $1997^{5}$. The fabrication procedures were the same as those used for the $\mathrm{Np} / \mathrm{Th}$ doped batch in the preceding section. $10 \mathrm{~mm}$ diameter and $\sim 0.5 \mathrm{~g}$ pellets were cold pressed at $\sim 90$ $\mathrm{MPa}$ and then sintered in an alumina tube furnace for 4 hours at $1350^{\circ} \mathrm{C}$. The atmospheres used were $0.25 \mathrm{l} / \mathrm{min}$ of $\mathrm{Ar}$ or air. The heating and cooling rate was $5^{\circ} \mathrm{C} / \mathrm{min}$.

\subsubsection{Glass Stabilisers}

$20 \mathrm{~g}$ batches of glass stabiliser powders of compositions given in Table 9 were made using the procedure used to make the Ce/U-doped samples in section 3.1.1.1 above.

Pellets from these materials were sintered at 1250,1300 or $1350^{\circ} \mathrm{C}$ in $\mathrm{Ar}$.

\subsection{Analysis}

After sintering, the densities of the samples were measured using Archimedes' method, in water for the Ce-doped samples and octanol for the Pu and Np-doped samples, via the evacuation method.

The samples were then mounted in resin and polished to a $0.25-1.0 \mu \mathrm{m}$ diamond finish. The polished surface was examined by X-ray diffraction (XRD), using either a Siemens D500 diffractometer employing Co K-alpha radiation, or a Scintag X1 Advanced Diffractometer System, with $\mathrm{Cu} \mathrm{K}$-alpha radiation. The samples were examined by scanning electron microscopy (SEM) using either a JEOL JSM6400 or JEOL JSM6300 machines, both of which are fitted with energy dispersive x-ray spectrometry (EDS) instruments for quantitative analysis.

\footnotetext{
${ }^{5}$ E.R. Vance, M.W.A. Stewart, R.A. Day, K.P. Hart, M.J. Hambley and A. Brownscombe, Pyrochlore-rich Titanate Ceramics for Incorporation of Plutonium, Uranium and Process Chemicals, ANSTO Report,
} 
Table 8: Compositions of the Task 1.4 Pu-doped batches containing the nominal impurity valency (wt. \%).

\begin{tabular}{|c|c|c|c|c|c|c|c|c|}
\hline Oxide $^{*}$ & $\begin{array}{c}\text { Batch } \\
\text { Precursor 5A } \\
\text { (Wt. \%) }\end{array}$ & $\begin{array}{c}\text { Batch } \\
2+ \\
\text { (Wt. \%) }\end{array}$ & Oxide $^{\#}$ & $\begin{array}{c}\text { Batch } \\
\text { Precursor 5A } \\
\text { (Wt. \%) }\end{array}$ & $\begin{array}{c}\text { Batch } \\
3+ \\
\text { (Wt. \%) }\end{array}$ & $\begin{array}{c}\text { Batch } \\
4+ \\
\text { (Wt. \%) }\end{array}$ & $\begin{array}{c}\text { Batch } \\
5+ \\
\text { (Wt. \%) }\end{array}$ & $\begin{array}{c}\text { Batch } \\
6+ \\
\text { (Wt. \%) }\end{array}$ \\
\hline $\mathrm{Al}_{2} \mathrm{O}_{3}$ & 0.11 & 0.09 & $\mathrm{Al}_{2} \mathrm{O}_{3}$ & 0.11 & 1.45 & 0.10 & 0.09 & 0.09 \\
\hline $\mathrm{CaO}$ & 9.85 & 8.17 & $\mathrm{CaO}$ & 9.85 & 8.84 & 8.86 & 8.59 & 8.59 \\
\hline $\mathrm{CoO}$ & & 2.61 & $\mathrm{CoO}$ & & & & & \\
\hline $\mathrm{Cr}_{2} \mathrm{O}_{3}$ & & & $\mathrm{Cr}_{2} \mathrm{O}_{3}$ & & 1.92 & & & \\
\hline $\mathrm{CuO}$ & & 2.76 & $\mathrm{CuO}$ & & & & & \\
\hline $\mathrm{FeO}$ & 0.14 & 2.58 & $\mathrm{Fe}_{2} \mathrm{O}_{3}$ & 0.16 & 2.30 & 0.14 & 0.14 & 0.14 \\
\hline $\mathrm{Ga}_{2} \mathrm{O}_{3}$ & & & $\mathrm{Ga}_{2} \mathrm{O}_{3}$ & & 2.53 & & & \\
\hline $\mathrm{Gd}_{2} \mathrm{O}_{3}$ & 7.87 & 6.53 & $\mathrm{Gd}_{2} \mathrm{O}_{3}$ & 7.87 & 7.06 & 7.08 & 6.86 & 6.86 \\
\hline $\mathrm{HfO}_{2}$ & 10.54 & 8.75 & $\mathrm{HfO}_{2}$ & 10.54 & 9.46 & 15.41 & 9.19 & 9.19 \\
\hline $\mathrm{MgO}$ & 0.46 & 1.77 & $\mathrm{MgO}$ & 0.46 & 0.41 & 0.41 & 0.40 & 0.40 \\
\hline $\mathrm{MnO}$ & & 2.42 & $\mathrm{Mn}_{2} \mathrm{O}_{3}$ & & 2.24 & & & \\
\hline $\mathrm{MoO}_{3}$ & 0.30 & 0.25 & $\mathrm{MoO}_{3}$ & 0.33 & 0.30 & 0.30 & 0.29 & 5.26 \\
\hline $\mathrm{Nb}_{2} \mathrm{O}_{5}$ & & & $\mathrm{Nb}_{2} \mathrm{O}_{5}$ & & & & 4.74 & \\
\hline $\mathrm{NiO}$ & & 2.59 & $\mathrm{NiO}$ & & & & & \\
\hline $\mathrm{PuO}_{2}$ & 11.77 & 9.76 & $\mathrm{PuO}_{2}$ & 11.77 & 10.57 & 10.58 & 10.26 & 10.27 \\
\hline $\mathrm{SnO}_{2}$ & & & $\mathrm{SnO}_{2}$ & & & 4.12 & & \\
\hline $\mathrm{Ta}_{2} \mathrm{O}_{5}$ & & & $\mathrm{Ta}_{2} \mathrm{O}_{5}$ & & & & 8.02 & \\
\hline $\mathrm{TiO}_{2}$ & 35.50 & 29.45 & $\mathrm{TiO}_{2}$ & 35.48 & 31.86 & 31.92 & 30.96 & 30.96 \\
\hline $\mathrm{UO}_{2}$ & 23.45 & 19.45 & $\mathrm{UO}_{2}$ & 23.44 & 21.05 & 21.09 & 20.45 & 20.45 \\
\hline $\mathrm{WO}_{3}$ & & & $\mathrm{WO}_{3}$ & & & & & 7.78 \\
\hline $\mathrm{ZnO}$ & & 2.83 & $\mathrm{ZnO}$ & & & & & \\
\hline $\mathrm{ZrO}_{2}$ & & & $\mathrm{ZrO}_{2}$ & & & 3.44 & & \\
\hline Total & 100.00 & 100.00 & Total & 100.00 & 100.00 & 100.00 & 100.00 & 100.00 \\
\hline
\end{tabular}

* Mn and $\mathrm{Fe}$ at 2+ valency state

\# Mn and Fe at 3+ valency state 
Table 9: Composition of the glass-doped material. Three grams of this composition was added to $20 \mathrm{~g}$ (oxide basis) of the baseline $\mathrm{Ce} / \mathrm{U}$-doped precursor.

\begin{tabular}{|l|cccc|}
\hline Batch No. & mws980209 & mws980368 & mws980369 & mws980370 \\
\hline & $\begin{array}{c}\text { Baseline Precursor } \\
+\end{array}$ & $\begin{array}{c}\text { Additional } \\
\mathrm{Al}_{2} \mathrm{O}_{3}\end{array}$ & $\begin{array}{c}\text { Additional } \\
\mathrm{B}_{2} \mathrm{O}_{3}\end{array}$ & $\begin{array}{c}\text { Additional } \\
\mathrm{Na}_{2} \mathrm{O} \& \mathrm{~K}_{2} \mathrm{O}\end{array}$ \\
Oxide & $\begin{array}{c}13 \text { wt. \% B3-13 } \\
\text { Wt. \% Oxide }\end{array}$ & Wt. \% Oxide & Wt. \% Oxide & Wt. \% Oxide \\
\hline $\mathrm{CaO}$ & 10.79 & 10.28 & 10.41 & 10.28 \\
$\mathrm{Gd}_{2} \mathrm{O}_{3}$ & 7.41 & 7.05 & 7.14 & 7.05 \\
$\mathrm{HfO}_{2}$ & 9.85 & 9.38 & 9.50 & 9.38 \\
$\mathrm{UO}_{2}$ & 21.95 & 20.90 & 21.17 & 20.91 \\
$\mathrm{CeO}_{2}$ & 7.07 & 6.73 & 6.82 & 6.74 \\
$\mathrm{TiO}_{2}$ & 33.59 & 31.97 & 32.40 & 31.99 \\
$\mathrm{Al}_{2} \mathrm{O}_{3}$ & 2.60 & 7.30 & 2.50 & 2.48 \\
$\mathrm{MgO}$ & 0.17 & 0.17 & 0.16 & 0.17 \\
$\mathrm{Ga}_{2} \mathrm{O}_{3}$ & 0.24 & 0.23 & 0.23 & 0.23 \\
$\mathrm{Fe}_{2} \mathrm{O}_{3}$ & 0.05 & 0.05 & 0.05 & 0.05 \\
$\mathrm{~K}_{2} \mathrm{O}$ & 0.09 & 0.08 & 0.08 & 2.94 \\
$\mathrm{Na}_{2} \mathrm{O}$ & 0.43 & 0.41 & 0.41 & 2.31 \\
$\mathrm{MoO}_{2}$ & 0.06 & 0.05 & 0.06 & 0.05 \\
$\mathrm{SiO}_{2}$ & 4.62 & 4.40 & 4.46 & 4.40 \\
$\mathrm{~B}_{2} \mathrm{O}_{3}$ & 0.71 & 0.67 & 4.24 & 0.68 \\
$\mathrm{P}_{2} \mathrm{O}_{5}$ & 0.35 & 0.33 & 0.33 & 0.33 \\
& & & & \\
\hline $\mathrm{Total}$ & 100.00 & 100.00 & 100.00 & 100.00 \\
\hline
\end{tabular}




\section{RESULTS AND DISCUSSION}

\subsection{Pyrochlore and Zirconolite Stabilisers Sintered in $\mathrm{Ar}$}

As discussed earlier, the addition of $\sim 13 \mathrm{wt}$. $\%$ of the nominally $2+$ to $6+$ impurity families was chosen so that each element was present at detectable levels for the SEM/EDS system and the impurity elements were present in sufficient amounts to saturate the baseline phases, resulting in the formation of new phases.

The SEM micrographs and EDS data have been placed in separate Appendices. SEM results are given in Appendices A - D; the X-ray diffraction results are given in Appendix $\mathrm{E}$; and the EDS results are in Appendix F.

\subsubsection{Ce/U-doped Samples Sintered at $1350^{\circ} \mathrm{C}$}

Densities of the Ce-doped samples are given in Table 10.

\subsubsection{Nominally 2+ impurities batch (Mg, Co, $\mathrm{Ni}, \mathrm{Cu}, \mathrm{Zn})$}

The SEM/EDS analysis (Appendix A, Fig. A-1/Appendix F, Table F-1) show that this sample consists of

- pyrochlore

- $\quad 15-20$ vol. $\%$ of what is believed to be $2 \mathrm{M}$ zirconolite

- $\quad 7$ - 10 vol. $\%$ ulvospinel

- $\quad 5$ vol. $\%$ perovskite

The pellet is deficient in $\mathrm{Cu}$ - it was only detected in the ulvospinel, at levels below those of the other nominally $2+$ elements (see Table F-1). Under the sintering conditions $\left(\mathrm{pO}_{2} \sim\right.$ $10^{-5} \mathrm{~atm}$.) $\mathrm{CuO}$ could be reduced to $\mathrm{Cu}$ metal; however metallic $\mathrm{Cu}$ was not detected in the microstructure and it may have volatilised, or flowed out of the sample. This is possible because the $\mathrm{Cu}$ would be molten at the sintering temperature, if it was metallic.

The sample may also be deficient in $\mathrm{Zn}$ (see Table F-1).

The pyrochlore contains small ( $0.03-0.08$ formula units) amounts of $\mathrm{Mg}$, Co and $\mathrm{Ni}$. The zirconolite, which we believe to be $2 \mathrm{M}$, contains $\sim 0.06-0.18$ formula units of $\mathrm{Mg}$, $\mathrm{Co}, \mathrm{Ni}$ and $\mathrm{Zn}$ (Table F-1). The perovskite contains $\mathrm{Gd}$ and Ce, and a trace of $\mathrm{U}$ and $\mathrm{Hf}$ plus $0.015-0.03$ formula units each of $\mathrm{Co}, \mathrm{Ni}$ and $\mathrm{Cu}$. Ce, $\mathrm{U}$ and $\mathrm{Gd}$ were not detected in the ulvospinel, which contained all the added nominally 2+ impurity elements, plus a trace of $\mathrm{Fe}$ and $\mathrm{Cr}$ from processing contaminants. The $\mathrm{Cu}$ in the ulvospinel is deficient relative to the rest of the nominally $2+$ impurity elements. 
Table 10: Densities of the Task 1.4 samples made from the Ce/U-doped precursor. Pellets were prepared by sintering for 4 hours at $1350^{\circ} \mathrm{C}$ in $\mathrm{Ar}$, air or $3.7 \% \mathrm{H}_{2}$ in Ar.

\begin{tabular}{|c|c|c|c|c|c|}
\hline Pellet No. & Powder Batch No. & Description & $\begin{array}{c}\text { Sintering } \\
\text { Atm. }\end{array}$ & $\begin{array}{c}\text { Archimedes } \\
\text { Density } \\
\left(\mathrm{g} / \mathrm{cm}^{3}\right)\end{array}$ & $\begin{array}{c}\text { Open } \\
\text { Porosity } \\
(\%)\end{array}$ \\
\hline mws980041 & mw980006 & Precursor mw980006 & $\mathrm{Ar}$ & 5.10 & 4.1 \\
\hline mws980042 & mw980006 & Precursor mw980006 & $\mathrm{Ar}$ & 5.10 & 3.3 \\
\hline mws 980070 & mws 980069 & Precursor mws 980069 & $\mathrm{Ar}$ & 4.82 & 3.3 \\
\hline mws980087 & mws980077 & $2+\mathrm{Mg}, \mathrm{Co}, \mathrm{Ni}, \mathrm{Cu}, \mathrm{Zn}$ & $\mathrm{Ar}$ & 5.09 & 0.4 \\
\hline mws980088 & mws980077 & $2+\mathrm{Mg}, \mathrm{Co}, \mathrm{Ni}, \mathrm{Cu}, \mathrm{Zn}$ & $\mathrm{Ar}$ & 4.95 & 0.5 \\
\hline mws980224 & mws980207 & $2+\mathrm{Mg}, \mathrm{Co}, \mathrm{Ni}, \mathrm{Cu}, \mathrm{Zn}, \mathrm{Mn}, \mathrm{Fe}$ & $\mathrm{Ar}$ & 4.74 & 3.1 \\
\hline mws980226 & mws980207 & $2+\mathrm{Mg}, \mathrm{Co}, \mathrm{Ni}, \mathrm{Cu}, \mathrm{Zn}, \mathrm{Mn}, \mathrm{Fe}$ & air & melted & \\
\hline mws980336 & mws980207 & $2+\mathrm{Mg}, \mathrm{Co}, \mathrm{Ni}, \mathrm{Cu}, \mathrm{Zn}, \mathrm{Mn}, \mathrm{Fe}$ & $3.7 \% \mathrm{H}_{2} / \mathrm{Ar}$ & 5.41 & 6.5 \\
\hline mws 980089 & mws980078 & $3+\mathrm{Al}, \mathrm{V}, \mathrm{Cr}, \mathrm{Mn}, \mathrm{Fe}, \mathrm{Ga}$ & $\mathrm{Ar}$ & 5.18 & 1.8 \\
\hline mws 980090 & mws 980078 & $3+\mathrm{Al}, \mathrm{V}, \mathrm{Cr}, \mathrm{Mn}, \mathrm{Fe}, \mathrm{Ga}$ & $\mathrm{Ar}$ & 5.08 & 7.2 \\
\hline mws980224 & mws980208 & $3+\mathrm{Al}, \mathrm{Cr}, \mathrm{Mn}, \mathrm{Fe}, \mathrm{Ga}$ & $\mathrm{Ar}$ & 4.10 & 1.8 \\
\hline mws980226 & mws980208 & $3+\mathrm{Al}, \mathrm{Cr}, \mathrm{Mn}, \mathrm{Fe}, \mathrm{Ga}$ & air & 4.09 & 3.0 \\
\hline mws980337 & mws980208 & $3+\mathrm{Al}, \mathrm{Cr}, \mathrm{Mn}, \mathrm{Fe}, \mathrm{Ga}$ & $3.7 \% \mathrm{H}_{2} / \mathrm{Ar}$ & 4.64 & 3.2 \\
\hline mws980091 & mws980079 & $4+\mathrm{Sn}, \mathrm{Zr}, \mathrm{Hf}$ & $\mathrm{Ar}$ & 4.81 & 0.3 \\
\hline mws980092 & mws980079 & $4+\mathrm{Sn}, \mathrm{Zr}, \mathrm{Hf}$ & $\mathrm{Ar}$ & 4.52 & 0.4 \\
\hline mws980201 & mws980079 & $4+\mathrm{Sn}, \mathrm{Zr}, \mathrm{Hf}$ & air & 3.87 & 11.0 \\
\hline mws980204 & mws980079 & $4+\mathrm{Sn}, \mathrm{Zr}, \mathrm{Hf}$ & $3.7 \% \mathrm{H}_{2} / \mathrm{Ar}$ & 5.43 & 3.4 \\
\hline mws 980093 & mws 980080 & $5+\mathrm{Nb}, \mathrm{Ta}$ & $\mathrm{Ar}$ & 5.36 & -0.6 \\
\hline mws980094 & mws980080 & $5+\mathrm{Nb}, \mathrm{Ta}$ & $\mathrm{Ar}$ & 5.25 & 0.2 \\
\hline mws980131 & mws980130 & $5+\mathrm{Nb}, \mathrm{Ta}$ & $\mathrm{Ar}$ & 5.38 & 0.8 \\
\hline mws980132 & mws980130 & $5+\mathrm{Nb}, \mathrm{Ta}$ & Ar & 5.40 & 1.3 \\
\hline mws980202 & mws980130 & $5+\mathrm{Nb}, \mathrm{Ta}$ & air & 5.38 & 1.6 \\
\hline mws 980205 & mws 980130 & $5+\mathrm{Nb}, \mathrm{Ta}$ & $3.7 \% \mathrm{H}_{2} / \mathrm{Ar}$ & 5.61 & 2.1 \\
\hline mws 980290 & mws980130 & $5+\mathrm{Nb}, \mathrm{Ta}$ & $3.7 \% \mathrm{H}_{2} / \mathrm{Ar}$ & 5.15 & 9.7 \\
\hline mws980095 & mws980081 & $6+\mathrm{Mo}, \mathrm{W}$ & $\mathrm{Ar}$ & 4.87 & 11.2 \\
\hline mws980096 & mws980081 & $6+\mathrm{Mo}, \mathrm{W}$ & $\mathrm{Ar}$ & 4.91 & 8.9 \\
\hline mws980203 & mws980081 & $6+\mathrm{Mo}, \mathrm{W}$ & air & 5.37 & 0.0 \\
\hline mws980206 & mws980081 & $6+\mathrm{Mo}, \mathrm{W}$ & $3.7 \% \mathrm{H}_{2} / \mathrm{Ar}$ & 5.79 & 3.3 \\
\hline mws980291 & mws980081 & $6+\mathrm{Mo}, \mathrm{W}$ & $3.7 \% \mathrm{H}_{2} / \mathrm{Ar}$ & 5.64 & 5.7 \\
\hline
\end{tabular}




\subsubsection{Nominally 2+ impurities batch with $\mathrm{Mn}$ and $\mathrm{Fe}(\mathrm{Mg}, \mathrm{Co}, \mathrm{Ni}, \mathrm{Cu}, \mathrm{Zn}, \mathrm{Fe}$, $\mathrm{Mn})$}

The SEM/EDS analysis (Appendix A, Fig. A-2/Appendix F Table F-2) show that this sample consists of:

- pyrochlore, which exhibits some compositional zoning

- 15-20 vol. \% of what is believed to be $2 \mathrm{M}$ zirconolite

- $\quad 10$ vol. $\%$ ulvospinel

- $\quad$ 5 vol. $\%$ perovskite

The results are generally similar to that of the above mentioned nominally $2+$ impurity sample without $\mathrm{Fe}$ and $\mathrm{Mn}$ (section 4.1.1.1). The pyrochlore contains small $(\sim 0.03-0.08$ formula units) amounts of Fe, Mn, Mg, Co and Ni (Table F-2). The zirconolite contains 0.04 - 0.16 formula units each of $\mathrm{Fe}, \mathrm{Mn}, \mathrm{Mg}, \mathrm{Co}, \mathrm{Ni}$ and $\mathrm{Zn}$ (Table F-2). The perovskite again contains $\mathrm{Gd}$ and $\mathrm{Ce}$ plus a trace of $\mathrm{U}$ and $\mathrm{Hf}$. The Ce believed to be in the 3+ state in the perovskite, though further work, such as XANES, would need to be done to confirm this. The perovskite also contains a small amount ( $~ 0.005-0.03$ formula units each) of $\mathrm{Mn}, \mathrm{Fe}, \mathrm{Co}, \mathrm{Ni}$ and $\mathrm{Cu}$. The ulvospinel contains all the added elements plus a trace of impurity $\mathrm{Cr}$. The Mn is slightly deficient in the ulvospinel.

\subsubsection{Nominally 3+ impurities batch with V (Al, V, Cr, Mn, Fe, Ga)}

The SEM/EDS analysis (Appendix A, fig. A-3/ Appendix F, Table F-3) show that this sample consists of:

- pyrochlore

- $\quad 30$ vol. $\%$ of what is believed to be $2 \mathrm{M}$ zirconolite

- $\sim 10$ vol. $\%$ of a titanate phase, possibly loveringite

The zirconolite is believed to be the $2 \mathrm{M}$ polytype, from the X-ray pattern. This is expected from the relatively large impurity doping of $3 \mathrm{~d}$ elements in the Ti sites, which necessitates charge compensation by $\mathrm{Ce}, \mathrm{U}$ and $\mathrm{Gd}$ substituting for $\mathrm{Ca}$ in the $\mathrm{Ca}$ site.

Approximately 0.38 formula units in total of the nominally $3+$ family of elements enter the pyrochlore. The elements partition approximately equivalently in the pyrochlore apart from $\mathrm{Mn}$, which is present in a slightly higher quantity. The $\mathrm{Fe}, \mathrm{V}, \mathrm{Cr}, \mathrm{Ga}, \mathrm{Mn}$ and $\mathrm{Al}$ are present in approximately equivalent amounts in the zirconolite. About 0.7 formula units in total of the family of nominally $3+$ elements enter the zirconolite. The $\mathrm{V}$ is deficient in the zirconolite. The "loveringite-like" phase contains approximately equivalent amounts of $\mathrm{Cr}$, $\mathrm{Ga}, \mathrm{Al}$ and $\mathrm{Fe}$, slightly less $\mathrm{V}$ and $\mathrm{Mn}$. Hence, V appears to be deficient in the sample.

The pellet has rounded grains (fig. A-3) and we believe this indicates localised melting. Vanadium is likely to exist as $\mathrm{V}^{5+}$ (vanadate), even under an argon atmosphere. Such metal vanadates are often used as a crystal growth flux at 1200_C. This does not preclude the existence of trivalent $\mathrm{V}$ as $\mathrm{V}$ is incorporated into the pyrochlore and zirconolite.

The existence of $\mathrm{Fe}$ and $\mathrm{Mn}$ at 2+ valency is a distinct possibility under the sintering conditions used. 
From the above results the $\mathrm{Al}, \mathrm{Cr}, \mathrm{Mn}, \mathrm{Fe}$ and $\mathrm{Ga}$ can be considered equivalent. This is because all of these elements can be nearly equally accommodated into the pyrochlore and zirconolite. The equivalence of $\mathrm{V}\left(\right.$ as $\left.\mathrm{V}^{3+}\right)$ is debatable. At the relatively large amounts used in this study, $\mathrm{V}$ induces melting, however, significant amounts are still incorporated into the pyrochlore and zirconolite, which probably indicates that $\mathrm{V}^{3+}$ is equivalent to the other $3+$ elements.

In view of the complications attributed to the use of $\mathrm{V}$, we repeated the experiment without V.

\subsubsection{Nominally 3+ impurities batch without V (Al, Cr, Mn, Fe, Ga)}

The SEM/EDS analysis (Appendix A, fig. A-4/ Appendix F, Table F-4) show that this sample consists of:

- pyrochlore

- $\quad 30$ vol. $\%$ of what is believed to be $2 \mathrm{M}$ zirconolite

- $\quad 5$ - 10 vol. $\%$ perovskite

- $\sim 5$ - 10 vol. $\%$ of a titanate phase, probably loveringite

The sample has a different microstructure to that of the V-doped batch above (section 4.1.1.3), in so far as it is more porous, contains a perovskite phase, and no liquid-phase sintering was apparent - in agreement with the idea expressed in section 4.1.1.3 that $\mathrm{V}$ resulted in local melting.

Approximately 0.31 formula units of the $3+$ family of elements enter the pyrochlore. The elements partition approximately equivalently within the pyrochlore, apart from $\mathrm{Mn}$, which is present in a slightly higher quantity. The $\mathrm{Fe}, \mathrm{Cr}, \mathrm{Ga}, \mathrm{Mn}$ and $\mathrm{Al}$ are present in approximately equivalent amounts in the zirconolite; about 0.7 formula units of the family of nominally $3+$ elements enter the zirconolite. The perovskite contains approximately equal amounts of $\mathrm{Al}, \mathrm{Ga}, \mathrm{Cr}$ and $\mathrm{Fe}$. The $\mathrm{Mn}$ and $\mathrm{Fe}$ are relatively deficient in the perovskite. The "loveringite-like" phase contains approximately equivalent amounts of $\mathrm{Cr}$ and $\mathrm{Fe}$, slightly less $\mathrm{Ga}$ and $\mathrm{Al}$, and significantly less $\mathrm{Mn}$.

\subsubsection{Nominally 4+ impurities batch (Zr, Sn, Hf)}

The SEM/EDS analysis (Appendix A, fig. A-5/Appendix F, Table F-5) show that this sample consists of

- pyrochlore

- 25 vol. $\% 4 \mathrm{M}$ zirconolite

- $\sim 25$ vol. $\% 2 \mathrm{M}$ zirconolite

- $\sim 7$ - 10 vol. $\%$ brannerite

- $\sim 5$ vol. $\%$ rutile

- $\quad 2$ - 5 vol. \% hafnium titanate $\left((\mathrm{Hf}, \mathrm{Zr}, \mathrm{Sn}) \mathrm{TiO}_{4}\right)$

The main effect of $\mathrm{Zr}$, Hf and Sn additions is to promote zirconolite formation at the expense of pyrochlore. Hafnium titanate also forms. Approximately equivalent amounts of $\mathrm{Sn}, \mathrm{Zr}$ and $\mathrm{Hf}$ can be found in the zirconolites, pyrochlore, hafnium titanate and rutile, with some minor variations, namely, that the $S n$ has a greater tendency to enter the pyrochlore and $4 \mathrm{M}$ zirconolite than $\mathrm{Hf}$ or $\mathrm{Zr}$. No Sn was detected in the brannerite. 


\subsubsection{Nominally $5+$ impurities batch $(\mathrm{Nb}, \mathrm{Ta})$}

The SEM/EDS analysis (Appendix A, fig. A-6/Appendix F Table F-6) show that this sample consists of:

- Pyrochlore

- $\quad 10$ vol. $\%$ brannerite

- $\quad 10$ vol. $\%$ rutile

Approximately 0.5 formula units of $\mathrm{Nb}+$ Ta enter the pyrochlore in the Ti site (i.e., $\sim 25$ $\%$ of the Ti sites are occupied by $\mathrm{Ta}$ or $\mathrm{Nb}$ in this batch). The rutile contains $\sim 0.07$ formula units of $\mathrm{Nb}+\mathrm{Ta}$ and the brannerite $\sim 0.14$ formula units of $\mathrm{Nb}+\mathrm{Ta}$; i.e., $\sim 7 \%$ of the Ti sites in these phases are occupied by $\mathrm{Ta}+\mathrm{Nb}$. No zirconolite formed. $\mathrm{The} \mathrm{Nb}$ and Ta evidently prefer to enter the pyrochlore. The $\mathrm{Nb}$ and Ta enter each phase in approximately equivalent amounts.

\subsubsection{Nominally 6+ impurities batch (Mo, W)}

The SEM/EDS analysis (Appendix A, fig. A-7/Appendix F, Table F-7) show that this sample consists of:

- Pyrochlore

- 20-25 vol. \% brannerite

- $\quad \sim 5$ vol. $\%$ rutile

- 10 vol. \% of a $\mathrm{Ca}(\mathrm{W}, \mathrm{Mo}) \mathrm{O}_{4}$ (scheelite/powellite) solid solution

Little, if any, Mo and $\mathrm{W}$ enter the brannerite or rutile. About 2-3 times as much $\mathrm{W}$ as Mo enters the pyrochlore. The total $\mathrm{W}$ and Mo in the pyrochlore is $\sim 0.2$ formula units. The $\mathrm{Ca}(\mathrm{W}, \mathrm{Mo}) \mathrm{O}_{4}$ contains about twice as much Mo as W. The presence of $\mathrm{W}$ and Mo above the solubility limits in pyrochlore has sequestered $\mathrm{Ca}$, leading to more brannerite formation.

\subsubsection{Pu/U-doped Samples Sintered in Ar at $1350^{\circ} \mathrm{C}$}

Densities of the pellets are given in Table 11.

\subsubsection{Nominally 2+ impurities batch with $\mathrm{Mn}$ and $\mathrm{Fe}(\mathrm{Mg}, \mathrm{Co}, \mathrm{Ni}, \mathrm{Cu}, \mathrm{Zn}, \mathrm{Fe}$, Mn)}

The SEM/EDS analysis (Appendix A, fig. A-8/Appendix F, Table F-8) show that this sample consists of:

- Pyrochlore which exhibits some zoning (fig. A-8)

- 10 vol. \% ulvospinel

The microstructure is different to the equivalent $\mathrm{Ce} / \mathrm{U}$-doped batch (section 4.1.1.2 above) in that $2 \mathrm{M}$ zirconolite and perovskite were not detected in the microstructure and the grain size was slightly larger. In addition, Ni was not detected in the pyrochlore, whereas it was detected in small amounts in the Ce/U-doped pyrochlore. The pyrochlore contains a similar amount of nominally $2+$ impurities to the Ce/U-doped batch ( $~ 0.3$ formula units). 
for Task 1.4. Pellets were prepared by sintering for 4 hours at $1350^{\circ} \mathrm{C}$ in $\mathrm{Ar}$ or air.

\begin{tabular}{|c|c|c|c|c|}
\hline Pellet No. & Description & $\begin{array}{c}\text { Sintering } \\
\text { Atm. }\end{array}$ & $\begin{array}{c}\text { Archimedes } \\
\text { Density } \\
\left(\mathrm{g} / \mathrm{cm}^{3}\right)\end{array}$ & $\begin{array}{c}\text { Open } \\
\text { Porosity } \\
(\%)\end{array}$ \\
\hline Pu107-01 & $2+\mathrm{Mg}, \mathrm{Co}, \mathrm{Ni}, \mathrm{Cu}, \mathrm{Zn}, \mathrm{Mn}, \mathrm{Fe}$ & $\mathrm{Ar}$ & 5.21 & 0.6 \\
\hline Pu107-02 & $2+\mathrm{Mg}, \mathrm{Co}, \mathrm{Ni}, \mathrm{Cu}, \mathrm{Zn}, \mathrm{Mn}, \mathrm{Fe}$ & air & 4.94 & 1.5 \\
\hline Pu108-01 & $3+\mathrm{Al}, \mathrm{Cr}, \mathrm{Mn}, \mathrm{Fe}, \mathrm{Ga}$ & $\mathrm{Ar}$ & 5.28 & 0.3 \\
\hline Pu108-02 & $3+\mathrm{Al}, \mathrm{Cr}, \mathrm{Mn}, \mathrm{Fe}, \mathrm{Ga}$ & air & 5.25 & 0.1 \\
\hline Pu109-01 & $4+\mathrm{Sn}, \mathrm{Zr}, \mathrm{Hf}$ & $\mathrm{Ar}$ & 5.80 & 0.1 \\
\hline Pu109-02 & $4+\mathrm{Sn}, \mathrm{Zr}, \mathrm{Hf}$ & air & 5.81 & 0.1 \\
\hline Pu110-01 & $5+\mathrm{Nb}, \mathrm{Ta}$ & $\mathrm{Ar}$ & 5.63 & 0.04 \\
\hline Pu110-02 & $5+\mathrm{Nb}, \mathrm{Ta}$ & air & 5.64 & 0.07 \\
\hline Pu111-01 & $6+$ Mo, W & $\mathrm{Ar}$ & 5.55 & 0 \\
\hline Pu111-02 & $6+\mathrm{Mo}, \mathrm{W}$ & air & 5.24 & 1.3 \\
\hline
\end{tabular}

\subsubsection{Nominally $3+$ impurities batch without V (Al, Cr, Mn, Fe, Ga)}

The SEM/EDS analysis (Appendix A, fig. A-9/Appendix F, Table F-9) show that this sample consists of:

- pyrochlore

- $\quad 25$ vol. $\% 2 \mathrm{M}$ zirconolite

- $\quad 5$ vol. $\%$ of what is believed to be magnetoplumbite

- $\sim 5 \mathrm{vol}$. $\%$ of what is probably a loveringite type phase

The distribution of the nominally 3+ elements is not exactly uniform. $\mathrm{Al}$ and $\mathrm{Ga}$ do not enter the pyrochlore in detectable amounts. $\mathrm{Mn}$ is present in similar amounts in the pyrochlore and $4 \mathrm{M}$ zirconolite. There is slightly more $\mathrm{Fe}$ and $\mathrm{Cr}$ in the $2 \mathrm{M}$ zirconolite than the pyrochlore. The Mg impurity in the precursor powder concentrates in magnetoplumbite and loveringite. $\mathrm{Mg}$ was not detectable in the pyrochlore and zirconolite. $\mathrm{Pu}$ and $\mathrm{U}$ are present in the pyrochlore, zirconolite and loveringite. All the phases contain neutron poison $\mathrm{Gd}$ and/or Hf, though Gd was not detectable in the loveringite.

The structure is different to the Ce/U-doped samples ( section 4.1.1.4 above) in that it was less porous and did not contain perovskite. The $\mathrm{Ce} / \mathrm{U}$ batch did not contain magnetoplumbite. However, the amount of the $3+$ elements in the pyrochlore $(\sim 0.3$ formula units) and zirconolite ( 0.7 formula units) is similar to the Ce/U-doped sample.

\subsubsection{Nominally 4+ impurities batch ( $\mathrm{Zr}, \mathrm{Sn}, \mathrm{Hf})$}

The SEM/EDS analysis (Appendix A, fig. A-10/Appendix F, Table F-10) show that this sample consists of:

- pyrochlore

- $~ 30-40$ vol. $\%$ of what is believed to be $2 \mathrm{M}$ zirconolite

- $\sim 10$ vol. $\%$ brannerite

- $\quad 10$ vol. \% hafnium titanate $\left((\mathrm{Hf}, \mathrm{Zr}, \mathrm{Sn}) \mathrm{TiO}_{4}\right)$

- $\quad$ 2-3 vol. $\%$ rutile 
- $\quad<1$ vol. \% $(\mathrm{Pu}, \mathrm{U}) \mathrm{O}_{2}$

The partitioning of the $\mathrm{Sn}, \mathrm{Hf}$ and $\mathrm{Zr}$ is approximately equivalent except that little if any, Sn enters the brannerite and the rutile appears to be slightly enriched in Hf with respect to $\mathrm{Zr}$ and $\mathrm{Sn}$. The results are similar to the equivalent $\mathrm{Ce} / \mathrm{U}$-doped batch (section 4.1.1.5).

\subsubsection{Nominally $5+$ impurities batch $(\mathrm{Nb}, \mathrm{Ta})$}

The SEM/EDS analysis (Appendix A, fig. A-11/Appendix F, Table F-11) show that this sample consists of:

- pyrochlore

- $\quad$ 10-15 vol. \% rutile.

- $\quad \sim 10$ vol. \% brannerite.

- $\quad<1$ vol. $\%(\mathrm{Pu}, \mathrm{U}) \mathrm{O}_{2}$

$\mathrm{The} \mathrm{Nb}$ and $\mathrm{Ta}$ are present in equivalent amounts in each phase. The $\mathrm{Nb}$ and $\mathrm{Ta}$ preferentially enter the pyrochlore.

The results are similar to the Ce/U-doped batches (section 4.1.1.6).

\subsubsection{Nominally 6+ impurities batch (Mo, W)}

The SEM/EDS analysis (Appendix A, fig. A-12/Appendix F, Table F-12) show that this sample consists of:

- pyrochlore.

- 20 vol. $\%$ brannerite.

- $\quad$ 5 vol. $\%$ rutile

- $\quad$ - 10 vol. \% scheelite/powellite $\left(\mathrm{Ca}(\mathrm{W}, \mathrm{Mo}) \mathrm{O}_{4}\right)$

There are only small amounts of Mo and $\mathrm{W}$ in the brannerite or rutile. About 3 times as much $\mathrm{W}$ as Mo enters the pyrochlore, on a molar basis. The $\mathrm{Ca}(\mathrm{W}, \mathrm{Mo}) \mathrm{O}_{4}$ contains about twice as much Mo as W.

The results are similar to the Ce/U-doped batches (section 4.1.1.7).

\subsubsection{Th/Np-doped Batches.}

The SEM/EDS analysis (Appendix A, fig. A-13/Appendix F, Table F-13) show that this sample consists of:

- pyrochlore

- 15 vol. \% Ce/Th/U/Np-brannerite.

- (Gd,Ce,Th,Np,U)O $\mathrm{O}_{2}$ ( 1-2 vol. \%), which contains equivalent amounts of Th and Np. The composition of this oxide is $\sim \mathrm{Ca}_{0.05} \mathrm{Gd}_{0.11} \mathrm{Ce}_{0.13} \mathrm{~Np}_{0.13} \mathrm{Th}_{0.13} \mathrm{U}_{0.50} \mathrm{Hf}_{0.02} \mathrm{Ti}_{0.01} \mathrm{O}_{2}$

The addition of approximately $15 \mathrm{wt}$. \% combined oxides of Th and $\mathrm{Np}$ to the baseline has saturated the system, consuming the excess Hf-doped rutile. A mixed Gd-Ce-Th-U-Np oxide forms from the rare-earth/actinide elements that are not incorporated in the pyrochlore or brannerite.

The Th tends to be enriched in the brannerite phase and deficient in the pyrochlore, relative to the $\mathrm{Np}$. The Th and Np partition equivalently in the actinide/rare earth oxide that 


\subsection{Sintering Atmosphere Effects on Pyrochlore and Zirconolite Stabilisers}

\subsubsection{Sintering Ce/U-doped Samples in Air}

Densities of the Ce/U-doped pellets are given in Table 10.

\subsubsection{Nominally 2+ impurities batch (Mg, Co, Ni, Cu, Zn, Fe, Mn)}

This sample showed local melting and was very porous (up to $\sim 1 \mathrm{~mm}$ diameter pores), but it had regions of low porosity between the pores.

The SEM/EDS analysis (Appendix B, Fig. B-1/Appendix F, Table F-2) show that this sample consists of:

- pyrochlore

- $\quad 15-20$ vol. $\%$ of $2 \mathrm{M}$ zirconolite

- $\quad 15$ vol. \% ulvospinel

The results are similar to the nominally $2+$ impurity batch sintered in $\operatorname{Ar}$ (section 4.1.1.2) except that no perovskite was detected and the composition of the pyrochlore is different it contains more $\mathrm{Ca}$ (Table F-2). The pyrochlore contained Fe, $\mathrm{Mn}, \mathrm{Mg}$ and $\mathrm{Co}$ and the zirconolite contained $\mathrm{Fe}, \mathrm{Mn}, \mathrm{Mg}, \mathrm{Co}, \mathrm{Ni}$ and $\mathrm{Zn}$ in detectable amounts. The ulvospinel contains all the added elements and a trace of $\mathrm{Cr}$. The $\mathrm{Mn}$ is slightly deficient in the ulvospinel.

In this sample, we would expect iron to be trivalent. In the EDS analysis, the Mn has been assumed to be trivalent, though it could be in the $4+$ state.

\subsubsection{Nominally 3+ impurities batch (Al, Cr, Mn, Fe, Ga)}

The SEM/EDS analysis (Appendix B, fig. B-2/Appendix F, Table F-4) show that this sample consists of:

- pyrochlore

- $~ 30-40$ vol. \% of what is believed to be $2 \mathrm{M}$ zirconolite

- $\sim 10$ vol. $\%$ of a titanate phase, which is probably a loveringite

The results are similar to the $3+$ batch sintered in $\operatorname{Ar}$ (section 4.1.1.2) except that no perovskite was detected and the pyrochlore contains more $\mathrm{Ca}$ (Table F-4), which changes the overall composition slightly. The nominally 3+ family of elements enter the pyrochlore. These elements partition approximately equivalently within the pyrochlore, with the exception of $\mathrm{Mn}$, which is present in a slightly higher quantity. The $\mathrm{Fe}, \mathrm{Cr}, \mathrm{Ga}$, $\mathrm{Mn}$ and $\mathrm{Al}$ are present in approximately equivalent amounts in the zirconolite. The "loveringite-like" phase contains approximately equivalent amounts of the 3+ elements, except for Mn, which is slightly deficient with respect to the other nominally $3+$ elements. 


\subsubsection{Nominally 4+ impurities batch ( $\mathrm{Zr}, \mathrm{Sn}, \mathrm{Hf})$}

The SEM/EDS analysis (Appendix B, fig. B-3/Appendix F, Table F-5) show that this sample consists of

- pyrochlore

- $\quad 15$ vol. $\% 2 \mathrm{M}$ zirconolite

- $\quad 15$ vol. \% hafnium titanate $\left((\mathrm{Hf}, \mathrm{Zr}, \mathrm{Sn}) \mathrm{TiO}_{4}\right)$

- $\sim 5$ vol. $\%$ rutile

Approximately equivalent amounts of $\mathrm{Sn}, \mathrm{Zr}$ and $\mathrm{Hf}$ can be found in the pyrochlore, zirconolite, hafnium titanate and rutile, with some minor variations, namely, that the $\mathrm{Sn}$ has a greater tendency to enter the pyrochlore than the zirconolite. No brannerite was detected.

The results are different to the Ar sinters (section 4.1.1.5) in that no brannerite was detected and the pyrochlore composition is different.

\subsubsection{Nominally $5+$ impurities batch $(\mathrm{Nb}, \mathrm{Ta})$}

The SEM/EDS analysis (Appendix B, fig. B-4/Appendix F, Table F-6) show that this sample consists of:

- pyrochlore

- 20 vol. $\%$ rutile

$\mathrm{The} \mathrm{Nb}$ and Ta prefer to enter the pyrochlore. Some $\mathrm{Nb}$ and Ta also enter the rutile. The $\mathrm{Nb}$ and Ta enter each phase in approximately equal amounts, to each other. Like the 4+ batch above (section 4.2.1.3). The major difference to the Ar sinters (section 4.1.1.6) is that no brannerite was detected.

\subsubsection{Nominally 6+ impurities batch (Mo, W)}

The SEM/EDS analysis (Appendix A, fig. B-5/Appendix F, Table F-7) show that this sample consists of:

- Pyrochlore

- $\quad 25$ vol. \% brannerite

- $\sim 5$ vol. $\%$ rutile

- 10 vol. \% of a $\mathrm{Ca}(\mathrm{W}, \mathrm{Mo}) \mathrm{O}_{4}$ (scheelite/powellite) solid solution

The results are the similar to the Ar sintered pellet (section 4.1.1.7, above) Little, if any, Mo and $\mathrm{W}$ enter the brannerite or rutile. About 2 to 3 times as much $\mathrm{W}$ as Mo enters the pyrochlore. The total $\mathrm{W}$ and Mo in the pyrochlore is $\sim 0.2$ formula units $\mathrm{The} \mathrm{Ca}(\mathrm{W}, \mathrm{Mo}) \mathrm{O}_{4}$ contains about twice as much Mo as W.

The pyrochlore has more Ca than the Ar sinter (Table F-7)

\subsubsection{Sintering Pu/U-doped Samples in Air}

Densities of the Pu/U-doped pellets are given in Table 10 . 


\subsubsection{Nominally 2+ impurities batch (Mg, Co, Ni, Cu, Zn, Fe, Mn)}

The SEM/EDS analysis (Appendix B, Fig. B-6/Appendix F, Table F-8) show that this sample consists of:

- pyrochlore, with some compositional zoning

- $\sim 15-20$ vol. $\%$ of $2 \mathrm{M}$ zirconolite

- $\sim 10$ - 15 vol. $\%$ ulvospinel

The results are similar to the nominally $2+$ impurity batch $\mathrm{Ce} / \mathrm{U}$ sintered in air (section 4.1.2.1) except that the composition of the pyrochlore is different - it contains more $\mathrm{Ca}$ (Table F-8). The pyrochlore contained Fe, $\mathrm{Mn}, \mathrm{Mg}$ and $\mathrm{Co}$ and the zirconolite contained $\mathrm{Fe}, \mathrm{Mn}, \mathrm{Mg}, \mathrm{Co}$ and $\mathrm{Ni}$, in detectable amounts. The ulvospinel contains all the added elements and a trace of $\mathrm{Cr}$. The $\mathrm{Mn}$ is slightly deficient in the ulvospinel. $\mathrm{Zn}$ was only detected in the ulvospinel. There is more $\mathrm{Cu}$ and $\mathrm{Zn}$ in the sample than in the Ar sintered sample (Table F-8).

\subsubsection{Nominally 3+ impurities batch (Al, $\mathrm{Cr}, \mathrm{Mn}, \mathrm{Fe}, \mathrm{Ga})$}

The SEM/EDS analysis (Appendix B, fig. B-7/Appendix F, Table F-10) show that this sample consists of:

- pyrochlore

- $~ 30-40$ vol. $\%$ of $2 \mathrm{M}$ zirconolite

- $~ 10$ vol. $\%$ of a loveringite-like phase

- $<1$ vol. \% brannerite

- $\quad<1$ vol. \% $(\mathrm{Pu}, \mathrm{U}) \mathrm{O}_{2}$

The nominally $3+\mathrm{Al}, \mathrm{Cr}, \mathrm{Mn}$ and Fe were detected in the pyrochlore. These elements partition approximately equivalently within the pyrochlore, with the exception of $\mathrm{Mn}$, which is present in a slightly higher quantity. All the $3+$ elements are present in approximately equivalent amounts in the zirconolite, except for $\mathrm{Ga}$, which is enriched. The loveringite contains approximately equivalent amounts of the 3+ elements, except for $\mathrm{Mn}$, which is slightly deficient, with respect to the other 3+ elements. Very small amounts $\left(<1\right.$ vol. \%) of brannerite and $(\mathrm{Pu}, \mathrm{U}) \mathrm{O}_{2}$ are present. The latter may have precipitated out of solution since it contains significant amounts of $\mathrm{Ca}$ and $\mathrm{Gd}$ as well as some $\mathrm{Hf}$ and $\mathrm{Ti}$ (Table F-9).

The results are similar to the Ar sinter (section 4.1.2.3) except that no magnetoplumbite was detected in this sample. As with the Ar sinter the main effect of the nominally 3+ elements has been to promote zirconolite formation at the expense of pyrochlore, with loveringite forming from the remaining $3+$ impurity elements.

\subsubsection{Nominally 4+ impurities batch (Zr, Sn, Hf)}

The SEM/EDS analysis (Appendix B, fig. B-8/Appendix F, Table F-10) show that this sample consists of

- pyrochlore

- $\quad 15$ vol. \% hafnium titanate $\left((\mathrm{Hf}, \mathrm{Zr}, \mathrm{Sn}) \mathrm{TiO}_{4}\right)$

- $\sim 5$ vol. $\% 2 \mathrm{M}$ zirconolite

- $\quad 3$ - 5 vol. $\%$ rutile 
- $\quad<1$ vol. \% $(\mathrm{Pu}, \mathrm{U}) \mathrm{O}_{2}$

Approximately equivalent amounts of $\mathrm{Sn}, \mathrm{Zr}$ and $\mathrm{Hf}$ can be found in the pyrochlore, zirconolites, hafnium titanate, brannerite and rutile, with some minor variations, namely, that the Sn has a greater tendency to enter the pyrochlore than $\mathrm{Hf}$ or $\mathrm{Zr}$.

\subsubsection{Nominally $5+$ impurities batch $(\mathrm{Nb}, \mathrm{Ta})$}

The SEM/EDS analysis (Appendix B, fig. B-9/Appendix F, Table F-11) show that this sample consists of:

- pyrochlore

- $\sim 10-15$ vol. $\%$ brannerite

- $\quad 15$ vol. $\%$ rutile

- $\quad<1$ vol. \% $(\mathrm{Pu}, \mathrm{U}) \mathrm{O}_{2}$

The results are similar to the Ar sintered batch (section 4.1.2.4). $\mathrm{Nb}$ and Ta prefer to enter the pyrochlore. Some $\mathrm{Nb}$ and $\mathrm{Ta}$ also enter the brannerite and rutile. The $\mathrm{Nb}$ and $\mathrm{Ta}$ enter each phase in approximately equal amounts, to each other. Like the $4+$ batch above (section 4.2.2.3) the major difference to the Ar sinters (section 4.1.1.5) is that no brannerite was detected and the pyrochlore composition is different.

\subsubsection{Nominally 6+ impurities batch (Mo, W)}

The SEM/EDS analysis (Appendix A, fig. B-10/Appendix F, Table F-12) show that this sample consists of:

- pyrochlore

- $~ 25$ vol. $\%$ brannerite

- $\sim 5$ vol. $\%$ rutile

- $\sim 10$ vol. \% of a $\mathrm{Ca}(\mathrm{W}, \mathrm{Mo}) \mathrm{O}_{4}$ (scheelite/powellite) solid solution

The results are the similar to the Ar sintered pellet (section 4.1.2.5). Little, if any, Mo and $\mathrm{W}$ enter the brannerite or rutile. About 2 - 3 times as much $\mathrm{W}$ as Mo enters the pyrochlore. The total $\mathrm{W}$ and $\mathrm{Mo}$ in the pyrochlore is $\sim 0.2$ formula units. The $\mathrm{Ca}(\mathrm{W}, \mathrm{Mo}) \mathrm{O}_{4}$ contains about twice as much Mo as W.

The pyrochlore has slightly more Ca than the Ar sinter (Table F-7)

As with the Ar sinter, the excess $\mathrm{W}$ and Mo forms powellite/scheelite. This has the effect of using up $\mathrm{Ca}$ from the system, which results in an increase in the amount of brannerite. 


\subsubsection{Sintering Ce/U-doped Samples in $3.7 \% \mathrm{H}_{2}$ in $\mathrm{Ar}$}

Densities of the Ce/U-doped pellets are given in Table 10.

\subsubsection{Nominally 2+ impurities batch (Mg, Co, Ni, Cu, Zn, Fe, Mn)}

The SEM/EDS analysis (Appendix C, Fig. C-1/Appendix F, Table F-2) show that this sample consists of:

- $4 \mathrm{M}$ zirconolite

- $\sim 25$ vol. $\%$ perovskite

- $\quad 5$ - 10 vol. \% of metallic alloys of variable composition (Co-Ni-Cu-Fe)

- $\quad 7$ vol. $\%$ of an unidentified magnesium titanate phase (Mg-Hf-Ti-O, which contains a trace of $\mathrm{Ca}, \mathrm{Al}, \mathrm{Mn}$ and $\mathrm{U})$.

The main phase has a different composition (Table F-2) to the pyrochlore in the Ar and air samples, and is believed to be $4 \mathrm{M}$ zirconolite. The composition of the main phase suggests that this phase lies close to the $4 \mathrm{M}$ zirconolite - pyrochlore boundary. This compositional change is probably due to $\mathrm{Ti}^{3+}$ formation. The $4 \mathrm{M}$ zirconolite contains some $\mathrm{Mg}$ and $\mathrm{Mn}$, but the other impurities were not detected. The perovskite, in which no nominally $2+$ elements were detected, formed because of the reducing conditions on sintering. The Co, $\mathrm{Ni}, \mathrm{Cu}$ and $\mathrm{Fe}$ have formed metallic alloys. The $\mathrm{Mg}$ forms an unidentified $\mathrm{Mg}-\mathrm{Ti}-\mathrm{O}$ phase. No ulvospinel formed. No $\mathrm{Zn}$ was detected in the microstructure. Presumably the $\mathrm{Zn}$ formed the metal and has volatilised. The system is also deficient in Mn.

\subsubsection{Nominally 3+ impurities batch (Al, $\mathrm{Cr}, \mathrm{Mn}, \mathrm{Fe}, \mathrm{Ga})$}

The SEM/EDS analysis (Appendix C, fig. C-2/Appendix F, Table F-4) show that this sample consists of:

- pyrochlore

- $\quad 30$ - 35 vol. \% 2M zirconolite

- $\quad 30$ - 35 vol. $\%$ perovskite

- $\quad 1$ vol. $\%$ hibonite

- $\sim 1$ vol. $\%$ of $\mathrm{Fe}_{3} \mathrm{Ga}$, which contains $\sim 2$ wt. $\% \mathrm{Cr}$

As with the $4 \mathrm{M}$ zirconolite in the $2+$ impurities sample above (section 4.2.3.1), the composition of what is believed to be pyrochlore, lies close to the pyrochlore-4M boundary. The pyrochlore has a much different composition (Table F-4) to the pyrochlore in the $\mathrm{Ar}$ and air sintered samples. This is probably due to $\mathrm{Ti}^{3+}$ formation occasioned by the reducing atmosphere on sintering. Some $\mathrm{Fe}_{3} \mathrm{Ga}$ forms, so under these conditions the $\mathrm{Ga}$ and $\mathrm{Al}$ are not exactly equivalent. $\mathrm{Ga}$ and $\mathrm{Fe}$ were not detected in the perovskite, zirconolite or pyrochlore. Some $\mathrm{Ga}$ is present in the hibonite. $\mathrm{Al}, \mathrm{Cr}$ and $\mathrm{Mn}$ partition into the pyrochlore, zirconolite and perovskite. $\mathrm{Mn}$ is enriched in the pyrochlore.

\subsubsection{Nominally 4+ impurities batch (Zr, Sn, Hf)}

The SEM/EDS analysis (Appendix C, fig. C-3/Appendix F, Table F-5) show that this sample consists of 
- $\quad$ pyrochlore

- 20 vol. \% 2M zirconolite

- $\sim 15$ vol. $\%$ perovskite

- $\sim 2$ - 3 metallic tin

The hydrogen has evidently reduced the $\mathrm{Sn}$ to the metallic state. Very little Sn, if any, remains in the other phases. The $\mathrm{Zr}$ and $\mathrm{Hf}$ partition equivalently in the remaining phases. As with the 2+, and 3+ samples above (sections 4.2.3.1 and 4.2.3.2), the main phase, which is believed to be pyrochlore lies close to the pyrochlore-4M zirconolite boundary. The pyrochlore has a different composition (Table F-5) to the pyrochlore in the Ar and air samples. This is probably due to $\mathrm{Ti}^{3+}$ formation on sintering under the reducing conditions.

\subsubsection{Nominally $5+$ impurities batch $(\mathrm{Nb}, \mathrm{Ta})$}

The SEM/EDS analysis (Appendix C, fig. C-4/Appendix F, Table F-6) show that this sample consists of:

- pyrochlore

- $10-15$ vol. $\% 2 \mathrm{M}$ zirconolite

- $\quad$ 7 vol. $\%$ rutile

$\mathrm{The} \mathrm{Nb}$ and Ta still prefer to enter the pyrochlore. Some $\mathrm{Nb}$ and $\mathrm{Ta}$ also enter the zirconolite and rutile. The $\mathrm{Nb}$ and $\mathrm{Ta}$ enter each phase in approximately equal amounts, to each other. The reducing conditions, which will produce $\mathrm{Ti}^{3+}$, have resulted in $2 \mathrm{M}$ zirconolite formation. No perovskite was detected in this sample. The valencies of the $\mathrm{Nb}$ and Ta are not known.

\subsubsection{Nominally 6+ impurities batch (Mo, W)}

The SEM/EDS analysis (Appendix C, fig. C-5/Appendix F, Table F-7) show that this sample consists of:

- pyrochlore

- $\sim 10$ vol. $\% 2 \mathrm{M}$ zirconolite

- $\sim 10$ vol. $\%$ perovskite

- $\quad 10$ vol. \% of metallic (W,Mo) alloys

Most of the $\mathrm{W}$ and Mo have formed a metallic alloy and only small amounts, much less than the Ar or air sintered samples, remain in the other phases. Perovskite has formed due to the reducing conditions on sintering 


\subsection{Batches Doped with Glass Formers (Al, B, K, $\mathrm{Na}, \mathrm{Si})$}

The densities of the "glass-doped" pellets made to date are given in Table 12.

\subsubsection{LLNL Glass-doped Batch}

Phases detected in the sample sintered at $1250^{\circ} \mathrm{C}$ (Appendix D, Fig. D-1/Appendix F, Table F-14) were:

- Pyrochlore

- $\sim 10$ vol. $\%$ of a silicate phase, probably a glass

- $\sim 10$ - 15 vol. $\% 2 \mathrm{M}$ zirconolite

- $\quad$ - 10 vol. $\%$ brannerite

- $\quad 3$ vol. $\%$ rutile

- $\sim 1$ vol. $\%$ plagioclase, associated with the glass

Most of the $\mathrm{Al}$ is in the silicate glass, with significant amounts taken up by the pyrochlore and zirconolite. Al was also found in all the other phases. The bulk of the $\mathrm{Na}$ is in the silicate glass with some of it being in the plagioclase. $\mathrm{K}$ was not detected in the crystalline phases or the glass.

Phases detected in the sample sintered at $1300^{\circ} \mathrm{C}$ (Appendix D, Fig. D-2/Appendix F, Table F-14) were:

- Pyrochlore

- $\quad 10$ vol. $\%$ of a silicate phase, probably a glass

- $\sim 10$ vol. $\% 2 \mathrm{M}$ zirconolite

- $\sim 10$ - 15 vol. $\%$ brannerite

- $\sim 3$ vol. $\%$ rutile

- $\sim 1$ vol. $\%$ of titanite

- $<1$ vol. \% plagioclase, associated with the glass

The compositions of the phases in the 1250 and $1350^{\circ} \mathrm{C}$ samples are similar, with some minor variations.

Phases detected in the sample sintered at $1350^{\circ} \mathrm{C}$ (Appendix D, Fig. D-3/Appendix F, Table F-14) were:

- Pyrochlore

- $\quad 10$ vol. $\%$ of a silicate phase, probably a glass

- $\sim 5$ vol. $\%$ rutile

- $\quad 5$ vol. $\% 2 \mathrm{M}$ zirconolite

- $\quad 3$ - 5 vol. $\%$ brannerite

The compositions of the $1350^{\circ} \mathrm{C}$ sample phases are very similar to the $1300^{\circ} \mathrm{C}$ sample.

At $1250^{\circ} \mathrm{C}$ the grain size of the pyrochlore is $\sim 2-4 \mu \mathrm{m}$, by $1300{ }^{\circ} \mathrm{C}$ the grain size is $\sim 5-$ $10 \mu \mathrm{m}$ and at $1350^{\circ} \mathrm{C}$ the grain size is similar to the $1300^{\circ} \mathrm{C}$ sintered sample. Apart from grain growth, the overall look of the pyrochlore grains ("blocky") does not change (figs. 
The brannerite grains grow from $\sim 5-10 \mu \mathrm{m}$ at $1250^{\circ} \mathrm{C}$ to $20-60 \mu \mathrm{m}$ at $1300^{\circ} \mathrm{C}$, however at $1350^{\circ} \mathrm{C}$ there is less brannerite and the grain size of this brannerite is reduced to $<5 \mu \mathrm{m}$. Presumably, the brannerite grains have been attacked by the glass.

Small amounts of a plagioclase were detected in the samples fired at 1250 and $1300^{\circ} \mathrm{C}$, but not the $1350^{\circ} \mathrm{C}$ sample. A small amount of titanite (sphene) was detected in the $1300^{\circ} \mathrm{C}$ sintered sample.

The sample sintered at $1300^{\circ} \mathrm{C}$ shows signs of partial melting and grain growth compared to the sample sintered at $1250^{\circ} \mathrm{C}$. Similar phases are present in both these batches, though the compositions of the phases in the two samples are different (Table F-14). There is less compositional difference between the 1300 and $1350^{\circ} \mathrm{C}$ samples (Table F-14).

\subsubsection{LLNL Glass-doped Batch With Additional Al}

Phases detected in the sample sintered at $1300^{\circ} \mathrm{C}$ (Appendix D, Fig. D-4/Appendix F, Table F-15) were:

- Pyrochlore

- $\quad 25$ vol. $\% 2 \mathrm{M}$ zirconolite

- $\sim 5$ - 10 vol. $\%$ brannerite

- $\sim 5$ vol. $\%$ rutile

- $\quad 3$ vol. $\%$ plagioclase

- $\sim 3$ vol. $\%$ of what is believed to be magnetoplumbite

- $\quad 2$ vol. $\%$ of a silicate phase, probably a glass

The addition of $\mathrm{Al}$ has changed the composition of the microstructure relative to the $1300^{\circ} \mathrm{C}$ sinter (section 4.3.1, above). There is less silicate phase - the grain size of this silicate phase is too small for accurate compositional analysis (emissions from the surrounding phases are picked up). The phases that form at the expense of the silicate phase are more plagioclase, a magnetoplumbite phase and more $2 \mathrm{M}$ zirconolite. The brannerite has a smaller grain size than that in the glass-doped batch sintered at $1300^{\circ} \mathrm{C}$ (section 4.3.1).

\subsubsection{LLNL Glass-doped Batch With Additional B}

Phases detected in the sample sintered at $1300^{\circ} \mathrm{C}$ (Appendix D, Fig. D-5/Appendix F, Table F-15) were:

- Pyrochlore

- $~ 10$ - 15 vol. \% 2M zirconolite

- $\sim 5$ vol. $\%$ brannerite

- $\sim 5$ vol. $\%$ rutile

- $\quad 10$ - 15 vol. $\%$ of a silicate phase, probably a glass

The addition of boron has changed the composition of the microstructure relative to the $1300^{\circ} \mathrm{C}$ sintered glass (section 4.3.1). There is no plagioclase or titanite and less brannerite. In addition, the grain size of the brannerite is much smaller - closer to that of the $1350^{\circ} \mathrm{C}$ glass-doped sinter (fig. D-3).

If $\mathrm{B}$ and $\mathrm{Al}$ were equivalent then this batch and the additional $\mathrm{Al}$ batch (section 4.3.2) should be the same. They are not and therefore B and Al are not equivalent in this system. 


\subsubsection{LLNL Glass-doped Batch With Additional $\mathrm{Na}$ and $\mathrm{K}$}

Phases detected in the sample sintered at $1300^{\circ} \mathrm{C}$ (Appendix D, Fig. D-6/Appendix F, Table F-15) were:

- Pyrochlore

- $15-20$ vol \% perovskite

- $10-15$ vol. \% 2M zirconolite

- $\sim 10$ vol. \% of a silicate phase, probably a glass

The addition of $\mathrm{Na}$ and $\mathrm{K}$ has changed the composition of the microstructure relative to the $1300^{\circ} \mathrm{C}$ sintered glass (section 4.3.1). There is no plagioclase, titanite or brannerite. The $\mathrm{Na}$ promotes the formation of a Na-Ce perovskite at the expense of these phases. The silicate phase had much less $\mathrm{Ca}$ but more $\mathrm{Na}$ and $\mathrm{K}$. Potassium was only detected in the glass. It appears to be deficient in the sample and is assumed to have volatilised. $\mathrm{Na}$ was detected in significant amounts in the perovskite, pyrochlore $2 \mathrm{M}$ zirconolite and glass. Therefore, Na and $\mathrm{K}$ are not equivalent in this system. 
Table 12 Densities of the glass-doped batches sintered in Ar for 4 hours at 1250 $1350^{\circ} \mathrm{C}$.

\begin{tabular}{|llllll|}
\hline Pellet No. & Powder No. & Description & $\begin{array}{l}\text { Sintering } \\
\text { Temperature } \\
\left({ }^{\circ} \mathrm{C}\right)\end{array}$ & $\begin{array}{l}\text { Sintered } \\
\text { Density } \\
\left(\mathrm{g} / \mathrm{cm}^{3}\right)\end{array}$ & $\begin{array}{l}\text { Open } \\
\text { Porosity }(\%)\end{array}$ \\
\hline mws980231 & mws980209 & Glass-doped & 1250 & 4.46 & 3.5 \\
mws980232 & mws980209 & Glass-doped & 1300 & 3.19 & 19.5 \\
mws980338 & mws980209 & Glass-doped & 1350 & 4.42 & \\
mws980388 & mws980368 & Glass-doped + Al & 1300 & 3.12 & 32.0 \\
mws980389 & mws980369 & Glass-doped + B & 1300 & 2.91 & 3.4 \\
mws980390 & mws980370 & Glass-doped + Na \& K & 1300 & 4.21 & 2.0 \\
& & & & & \\
\hline
\end{tabular}

\subsection{Summary of Results}

\subsubsection{Firing Atmosphere Effects}

Generally, firing in air produces similar results to firing in Ar, with a few variations; namely, that the pyrochlore fired in air has more $\mathrm{Ca}$ in it and there is less likelihood of forming brannerite.

Sintering in hydrogenous atmospheres is not equivalent to Ar or air - phases such as perovskite, tin and metallic alloys form. The composition of the pyrochlores and zirconolites also change.

\subsubsection{Nominally 2+ Impurity Elements (Mg, Co, $\mathrm{Ni}, \mathrm{Cu}, \mathrm{Zn}, \mathrm{Fe}, \mathrm{Mn}$ )}

Partitioning of the nominally $2+$ impurity elements is not exactly uniform. The nominally $2+$ impurity elements are preferentially partitioned in the zirconolite ( $\sim .6$ formula units) compared to the pyrochlore ( 0.17 formula units). The presence of excess amounts of the $2+$ elements has resulted in the formation of an ulvospinel and some perovskite. There are subtle differences in the partitioning, such as the fact that little, if any, Zn enters the pyrochlore and $\mathrm{Mn}$ prefers to partition into the pyrochlore. Despite these variations, we can consider the $\mathrm{Co}, \mathrm{Ni}, \mathrm{Fe}, \mathrm{Mn}$ and $\mathrm{Mg}$ to be equivalent, as they will all enter the pyrochlore-zirconolite phases. The $\mathrm{Zn}$ is only partially equivalent as it may be volatile to some extent, but it can be accommodated into the $2 \mathrm{M}$ zirconolite. $\mathrm{Cu}$ is also not considered to be equivalent as it appears to be volatile when sintered in Ar. In the air sintered $\mathrm{Pu} / \mathrm{U}$-doped sample some $\mathrm{Cu}$ was detected in the $2 \mathrm{M}$ zirconolite.

The charge compensation for the $2+$ elements substituted in the Ti site occurs by rare-earth - actinide substitution in the Ca site of the pyrochlore and zirconolite. A typical baseline formulation has $\sim 0.9-0.95$ formula units of $\mathrm{Ca}$ in the pyrochlore ${ }^{5}$ and the samples with the $5+$ and $6+$ elements have 0.93 to 1.0 formula units of $\mathrm{Ca}$. When 2 and $3+$ elements are present the $\mathrm{Ca}$ is typically in the range $0.79-0.86$ formula units

\subsubsection{Nominally 3+ Impurity Elements (Al, Cr, Mn, Fe, Ga, V)}


From the above results the $\mathrm{Al}, \mathrm{Cr}, \mathrm{Mn}, \mathrm{Fe}, \mathrm{Ga}$ and probably the $\mathrm{V}$ (if we ignore the fluxing effect) can be considered equivalent. This is because all of these elements can be accommodated into the pyrochlore and zirconolite. In hydrogenous sintering atmospheres the $\mathrm{Fe}$ and $\mathrm{Ga}$ form $\mathrm{Fe}_{3} \mathrm{Ga}$, which contains some $\mathrm{Cr}$, and are therefore not equivalent to the other elements. $\mathrm{Al}, \mathrm{Mn}$ and $\mathrm{Cr}$ are approximately equivalent under these conditions.

The charge compensation mechanisms are broadly similar to those of the $2+$ elements.

\subsubsection{Nominally 4+ Impurity Elements (Zr, Sn, Hf)}

Based on these results the $\mathrm{Hf}$ and $\mathrm{Zr}$ and $\mathrm{Sn}$ can be considered equivalent under Ar and air sintering conditions. In hydrogenous atmospheres the $\mathrm{Sn}$ is reduced to metal and is not equivalent.

\subsubsection{Nominally 5+ Impurity Elements ( $\mathrm{Nb}, \mathrm{Ta})$}

The $\mathrm{Nb}$ and $\mathrm{Ta}$ enter each phase in approximately equal amounts, hence the $\mathrm{Nb}$ and $\mathrm{Ta}$ can be considered equivalent. The sintering atmosphere does not affect the equivalence. $\mathrm{The} \mathrm{Nb}$ and $\mathrm{Ta}$ enter the Ti sites in the pyrochlore; charge compensation proceeds by forcing the trivalent rare earths from the $\mathrm{Ca}$ to the $\mathrm{Zr}-\mathrm{Hf}$ site in the pyrochlore. This can be seen in the increase in $\mathrm{Ca}$ in the pyrochlore, particularly in the Pu-doped samples (Table F11). In the Ce-doped samples some charge compensation may also occur by the reduction of $\mathrm{Ce}$ from $\mathrm{Ce}^{4+}$ to $\mathrm{Ce}^{3+}$ if sintered under sufficiently reducing conditions.

\subsubsection{Nominally 6+ Impurity Elements (Mo, W)}

Based on the above results, the $\mathrm{W}$ and Mo can be closely considered equivalent. The charge compensation mechanisms are broadly similar to those of the 5+ elements.

\subsubsection{Th/Np-doped Batch}

The Th and $\mathrm{Np}$ do not behave exactly equivalently in that the Th tends to be enriched in the brannerite phase and deficient in the pyrochlore, relative to the $\mathrm{Np}$. The $\mathrm{Th}$ and $\mathrm{Np}$ do partition equivalently in the actinide/rare earth oxide that formed. Since significant amounts of $\mathrm{Np}$ and Th can be incorporated into the brannerite and pyrochlore phases, we believe that $\mathrm{Np}$ and $\mathrm{Th}$ can be considered equivalent for the purposes of this project.

\subsubsection{Glass-forming Elements}

The $\mathrm{Al}$ and $\mathrm{B}$ are not equivalent. The $\mathrm{Al}$ tends to result in zirconolite formation, whereas the $\mathrm{B}$ is believed to remain in the glass. As found in last year's work ${ }^{5}$, we believe that the $\mathrm{Na}$ and $\mathrm{K}$ may be volatile, or partially volatile. $\mathrm{Na}$ can be accommodated in the zirconolite and pyrochlore. If sufficient quantities are present, $\mathrm{Na}$ will promote the formation of a Narare-earth perovskite. Na can also be found in the plagioclase and the silicate phase. K was only found in the silicate phase of the sample made with additional $\mathrm{Na}$ and $\mathrm{K}$. Therefore, $\mathrm{Na}$ and $\mathrm{K}$ are not considered equivalent. 